\title{
A Villányi-hegység törmeléklejtő-erdei [Tilio tomentosae-Fraxinetum orni (A. O. Horvát 1958) Soó \& Borhidi in Soó 1962]
}

\author{
KeVEy BaLÁZS \\ Pécsi Tudományegyetem, Ökológiai Tanszék; 7624 Pécs, Ifjúság u. 6. \\ e-mail: keveyb@gamma.ttk.pte.hu
}

Kevey, B.: Scree forests [Tilio tomentosae-Fraxinetum orni (A.O. HoRVÁt 1961) Soó \& BoRHIDI in Soó 1962] in the Villány Mountains.

Abstract: This paper summarizes the phytosociological characteristics of scree forests (Tilio tomentosaeFraxinetum orni) found in the Villány Hills, SW Hungary. The studied stands grow within the belt of oakhornbeam forests on northerly slopes covered with stony soil. They are under relatively strong sub-Mediterraneam climatic influence as attested by the occurrence of several Aremonio-Fagion and Quercion farnetto species : Asperula taurina, Doronicum orientale, Helleborus odorus, Lathyrus venetus, Lonicera caprifolium, Lunaria annua, Polystichum setiferum, Primula vulgaris, Rosa arvensis, Ruscus aculeatus, Ruscus hypoglossum, Scutellaria altissima, Tamus communis and Tilia tomentosa. The distribution of character species proportions is similar to that in the scree forests in the Mecsek Hills, with the exception of Quercetea pubescentispetraeae s.l. as well as Fagetalia and Tilio-Acerenion species that play a more and a less significant role, respectively. Syntaxonomically, this community is best assigned to the „Polysticho setiferi-Acerenion pseudoplatani BORHIDI \& KEVEY 1996" suballiance.

Keywords: Syntaxonomy, Villány Mountains, sub-Mediterranean forest community, SW. Hungary.

\section{Bevezetés}

A Villányi-hegység törmeléklejtö-erdeinek társulási viszonyait eddig alig vizsgálták. BorHIDI (ined.) készített az 1960-as évek elején a Szársomlyóról öt cönológiai felvételt, de ezek közöletlenek maradtak. Mivel HorváT (1972) vegetációmúve sem tett említést e társulás Villányi-hegységben történő előfordulásáról, elhatároztam, hogy felkeresem a hegység törmeléklejtö-erdeit. A részletes terepbejárások alatt a Szársomlyó mellett a Fekete-hegyen és a Tenkesen is elökerült néhány állomány. Ezekből 1982 és 2015 között 15 cönológiai felvételt készítettem. Jelen tanulmányban e felvételi anyag alapján jellemzem a Villányi-hegység törmeléklejtö-erdeit. 


\section{Anyag és módszer}

\section{Kutatási terület jellemzése}

A Villányi-hegység geológiai felépítése nem túl változatos. Nagyrészt mészkő, kisebb részben pedig dolomit képezi, amelyet föleg az északi lejtőkön vastag lösztakaró fedi (Lovász \& WeIN 1974). A hegység hüvös és párás mikroklímájú, északias kitettségü (ÉNy, É, ÉK), meredekebb (30-45 fok) lejtőin néhol kisebb kiterjedésü törmeléklejtőerdők találhatók. A vizsgált állományok 250 és 380 m közötti tengerszint feletti magasság mellett találhatók üde, kőtörmelékes, rendzina szerü talajon.

\section{Alkalmazott módszerek}

A cönológiai felvételek a Zürich-Montpellier növénycönológiai iskola (BECKING 1957, BRAun-BlanQUET 1964) hagyományos kvadrát-módszerével készültek. A felvételek táblázatos összeállítása, valamint a karakterfajok csoportrészesedésének és csoporttömegének kiszámítása az „NS” számítógépes programcsomaggal (KEVEY \& HiRMANN 2002) történt. A felvételkészítés és a hagyományos statisztikai számítások kissé módosított - módszerét korábban részletesen közöltem (KEvEY 2008). A SYNTAX 2000 program (PODANI 2001) segítségével bináris ordinációt végeztem (Futtatási mód: fökoordináta-analízis; Koefficiens: BARONI-URBANI \& BUSER).

A fajok esetében KIRÁly (2009), a társulásoknál pedig BorHIDI \& KEVEY (1996), Borhid et al. (2012), ill. KeVEY (2008) nómenklatúráját követem. A társulástani és a karakterfaj-statisztikai táblázatok felépítése az újabb eredményekkel (OBERDORFER 1992; Mucina et al. 1993; BorHidi et al. 2012; KeVEy 2008) módosított Soó (1980) féle cönológiai rendszerre épül. A növények cönoszisztematikai besorolásánál is elsősorban Soó $(1964,1966,1968,1970,1973,1980)$ Synopsis-ára támaszkodtam, de figyelembe vettem az újabb kutatási eredményeket is (vö. BorHIDI 1993, 1995; HorváTH F. et al. 1995; KeVEY ined.).

\section{Eredmények}

\section{Fiziognómia}

A vizsgált törmeléklejtö-erdök 15-20 m magasak, felső lombkoronaszintjük közepesen záródó (60-75\%). Állandó (K: IV-V) fajai az Acer campestre, az Acer platanoides, a Fraxinus ornus, a Tilia platyphyllos és a Tilia tomentosa, Ulmus glabra. Tömeges (A-D: 3-4) fái a Acer campestre, a Fraxinus ornus, a Tilia tomentosa és a Tilia platyphyllos. Mellettük egyéb elegyfák is előfordulhatnak: Carpinus betulus, Cerasus avium, Fagus sylvatica, Pyrus pyraster, Quercus cerris, Quercus petraea, Quercus pubescens, Sorbus torminalis. Az alsó lombkoronaszint változóan fejlett. Magassága 10-15 m, borítása pedig 20-50\%. Főleg alászorult fák, kisebb részben fává nőtt cserjék (Corylus avellana, Cornus mas, Crataegus monogyna, Sambucus nigra, Staphylea pinnata) alkotják. Állandó (K: IV-V) fajai az Acer campestre, a Fraxinus ornus, a Tilia tomentosa és az Ulmus glabra. E szintben nagyobb borítást (A-D: 3) csak a Fraxinus ornus ér el.

A cserjeszint fejlett. Magassága 2-3,5 m, borítása pedig 30-70\%. Részben cserjék, részben pedig a lombkoronaszint fáinak fiatal egyedei képezik. Viszonylag állandó (K: IV-V) fajai a következök: Acer campestre, Acer platanoides, Cornus mas, Crataegus monogyna, Euonymus verrucosus, Fraxinus ornus, Ligustrum vulgare, Rosa canina agg., Sambucus nigra, Staphylea pinnata, Tilia tomentosa. Nagyobb tömegben (A-D: 4) 
elöforduló cserjéje csak a Cornus mas. Az alsó cserjeszint (újulat) borítása legtöbbször 1, de néha a $15 \%$-ot is elérheti, tehát tág határok között változik. Állandó (K: IV-V) fajai a következők: Acer campestre, Acer platanoides, Clematis vitalba, Crataegus monogyna, Euоnymus europaeus, Euonymus verrucosus, Fraxinus ornus, Hedera helix, Ligustrum vulgare, Sambucus nigra, Staphylea pinnata, Tilia tomentosa, Ulmus glabra. Fáciesképző faj e szintben nincs.

A gyepszint borítása nagyon változó (30-85\%). Állandó (K: IV-V) fajai az alábbiak: Alliaria petiolata, Anemone ranunculoides, Arum orientale, Asperula taurina, Asplenium trichomanes, Brachypodium sylvaticum, Bromus ramosus, Chaerophyllum temulum, Chelidonium majus, Clinopodium vulgare, Corydalis cava, Corydalis solida, Dactylis polygama, Euphorbia amygdaloides, Fallopia dumetorum, Fragaria vesca, Gagea lutea, Galanthus nivalis, Galeobdolon luteum, Geranium robertianum, Geum urbanum, Glechoma hirsuta, Helleborus odorus, Hylotelephium telephium, Lamium maculatum, Lapsana communis, Melica uniflora, Mercurialis perennis, Polygonatum multiflorum, Pulmonaria officinalis, Ranunculus ficaria, Ruscus aculeatus, Scutellaria altissima, Tamus communis, Veronica sublobata, Viola odorata. Közülük csak a Corydalis cava, és a Ruscus aculeatus képez fáciest.

\section{Fajkombináció}

\section{Állandósági osztályok eloszlása}

Az 50 cönológiai felvétel alapján a társulásban 36 konstans (K V) és 20 szubkonstans (K IV) faj szerepel az alábbiak szerint: - K V: Acer campestre, Acer platanoides, Alliaria petiolata, Asplenium trichomanes, Chelidonium majus, Cornus mas, Corydalis cava, Corydalis solida, Crataegus monogyna, Dactylis polygama, Euonymus verrucosus, Fallopia dumetorum, Fraxinus ornus, Gagea lutea, Galanthus nivalis, Galeobdolon luteum, Geranium robertianum, Geum urbanum, Glechoma hirsuta, Hedera helix, Helleborus odorus, Hylotelephium telephium, Lapsana communis, Ligustrum vulgare, Melica uniflora, Polygonatum multiflorum, Ranunculus ficaria, Rosa canina agg., Ruscus aculeatus, Sambucus nigra, Scutellaria altissima, Staphylea pinnata, Tilia tomentosa, Ulmus glabra, Veronica sublobata, Viola odorta. - K IV: Anemone ranunculoides, Arum orientale, Asperula taurina, Brachypodium sylvaticum, Bromus ramosus, Carpinus betulus, Cerasus avium, Chaerophyllum temulum, Clematis vitalba, Clinopodium vulgare, Euonymus europaeus, Euphorbia amygdaloides, Fragaria vesca, Lamium maculatum, Mercurialis perennis, Pulmonaria officinalis, Quercus cerris, Rosa arvensis, Tamus communis, Tilia platyphyllos. Ezen kívül 16 akcesszórikus (K III), 29 szubakcesszórikus (K II) és 77 akcidens (K I) faj került elö (vö. 1. táblázat). Az állandósági osztályok fajszámát tekintve tehát a konstans (K V) és az akcidens (K I) fajoknál jelentkezik egy-egy maximum, míg a minimum az akcesszórikus (K III) elemeknél van (1. ábra).

\section{Karakterfajok aránya}

Mint általában a törmeléklejtő-erdőkben, jelen esetben is a Fagetalia jellegü elemek kiemelkedő szerepet, játszanak, amelyek 22,0\% csoportrészesedést és $21,3 \%$ csoporttömeget mutatnak, arányuk tehát kisebb, mint a Mecseken, és szintén kevesebb, mint a Villányi-hegység egyéb Fagetalia erdeiben (3-4. táblázat; 2. és 6. ábra): K V: Acer platanoides, Arum orientale, Corydalis cava, Corydalis solida, Gagea lutea, Galanthus nivalis, Galeobdolon luteum, Glechoma hirsuta, Hedera helix, Polygonatum multiflorum, Ulmus glabra. - K IV: Anemone ranunculoides, Carpinus betulus, Cerasus avium, Euphorbia amygdaloides, Mercurialis perennis, Pulmonaria officinalis. - K III: 
Cardamine bulbifera, Lilium martagon, Moehringia trinervia, Stellaria holostea. - K II: Adoxa moschatellina, Carex pilosa, Fagus sylvatica, Galium odoratum, Isopyrum thalictroides, Scilla vindobonensis, Viola reichenbachiana. - K I: Allium ursinum, Arum maculatum, Dryopteris filix-mas, Epipactis helleborine agg., Lathraea squamaria, Lathyrus vernus, Milium effusum, Primula vulgaris, Ribes uva-crispa, Rubus hirtus, Salvia glutinosa.

A törmeléklejtő-erdők jellegét elsősorban a Tilio-Acerenion jellegü fajok adják, amelyek jelenesetben 3,8\% csoportrészesedést és $4,0 \%$ csoporttömeget mutatnak. Arányuk tehát kisebb, mint a Mecseken (4. táblázat, 7. ábra), de így is több, mint a Villányihegység bükköseiben és gyertyános-tölgyeseiben (3. táblázat, 3. ábra): $-\mathrm{K}$ V: Acer platanoides, Asplenium trichomanes, Staphylea pinnata, Ulmus glabra. - K IV: Tilia platyphyllos. - K III: Cystopteris fragilis, Gagea minima. - K II: Polypodium vulgare. - K I: Lunaria annua, Polystichum setiferum, Ribes-uva-crispa.

A Villányi-hegység törmeléklejtö-erdeinek sajátos megjelenését az Aremonio-Fagion csoportba sorolható szubmediterrán és illír jellegü fajok adják. Ezek némelyike Quercion farnetto jelleget is mutat: K V: Helleborus odorus, Ruscus aculeatus, Scutellaria altissima, Tilia tomentosa. - K IV: Asperula taurina, Rosa arvensis, Tamus communis. - K II: Doronicum orientale, Lonicera caprifolium. - K I: Lathyrus venetus, Lunaria annua, Primula vulgaris, Polystichum setiferum, Ruscus hypoglossum. Csoportrészesedésük 4,4\%, amely alig több, mint a Mecseken. Csoporttömegük ezzel szemben $10,0 \%$, tehát mintegy kétszer annyi, mint a Nyugati-Mecseken, és négyszer annyi, mint a Keleti-Mecseken. Mindez elsősorban a Ruscus aculeatus és a Tilia tomentosa tömeges elöfordulásával hozható összefüggésbe (3-4. táblázat; 4. és 9. ábra).

Nagy számmal fordulnak elő Querco-Fagetea (16,9\% csoportrészesedés, 9,7\% csoporttömeg), és a Quercetea pubescentis-petraeae (18,1\% csoportrészesedés, 20,5\% csoporttömeg) elemek is. Utóbbiak a vizsgált törmeléklejtő-erdőkben jelentősebb szerepet játszanak, mint a Villányi-hegység bükköseiben és gyertyános-tölgyeseiben, valamint a Mecsek törmeléklejtö-erdeiben (3-4. táblázat; 5. és 9. ábra).

\section{Sokváltozós statisztikai elemzések eredményei}

A Villányi-hegység törmeléklejtő-erdeit sokváltozós elemzéssel is megvizsgáltam úgy, hogy a vizsgálatba a szurdokerdők (KEVEY 1987), a bükkösök (KEVEY 1987) és a gyertyános-tölgyesek (KeVEY 2016) mellett a Nyugati- és a Keleti-Mecsek törmeléklejtöerdeit (KeVEY - BORHIDI 1998; KeVEY 2007) is belevontam.

Ha a Villányi-hegység Fagetalia erdőtársulásait vizsgáljuk (10. ábra), akkor a törmeléklejtő-erdők felvételei a dendrogram jobb felső részén találhatók, bár nem különülnek el élesen az ábra középső részén levő gyertyános-tölgyesek felvételeitöl. A bükkösök felvételei jórészt a dendrogram bal felső részén foglalnak helyet, de ezek sem különülnek el egyértelmüen a gyertyános-tölgyesektöl. A szurdokerdők öt felvétele a gyertyános-tölgyesek felvételei közé keveredve található. Végül a Villányi-hegység és a Mecsek törmeléklejtő-erdei viszonylag jól elkülönülnek (11. ábra). 


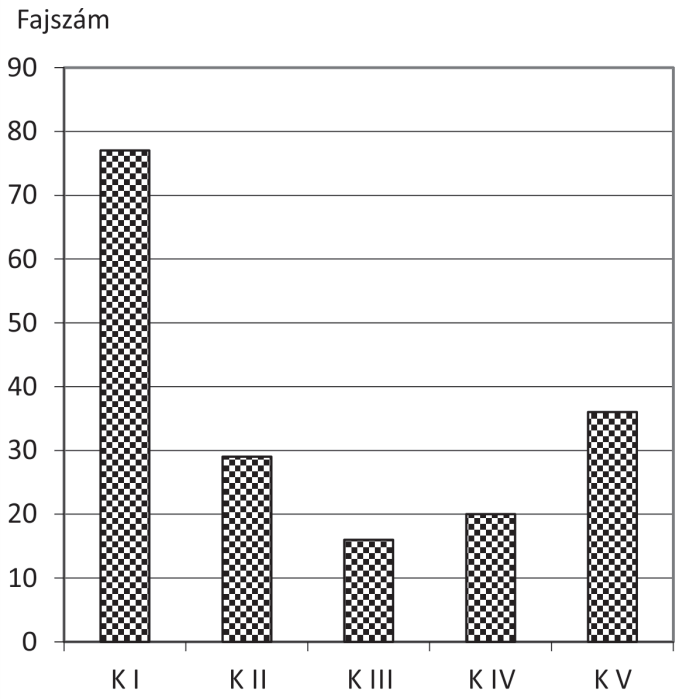

1. ábra: Állandósági osztályok eloszlása



2. ábra: Fagetalia elemek aránya a Villányi-hegység mezofil lomberdeiben

T: törmeléklejtő-erdő (Tilio tomentosae-Fraxinetum orni) (KevEY ined.: 15 felv.), Ac: szurdokerdő (Scutellario altissimae-Aceretum pseudoplatani) (KeVEY 1985: 5 felv.) Cp: gyertyános-tölgyes (Asperulo taurinaeCarpinetum) (Kevey 2016: 50 felv.), F: bükkös (Helleboro odori-Fagetum) (Kevey 1987: 50 felv.) 


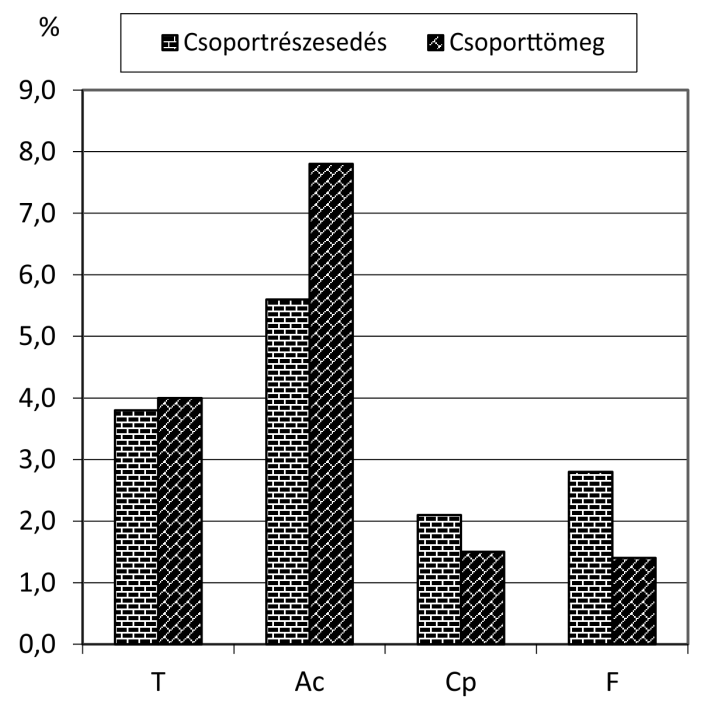

\section{3. ábra: Tilio-Acerenion elemek aránya a Villányi-hegység mezofil lomberdeiben}

T: törmeléklejtő-erdő (Tilio tomentosae-Fraxinetum orni) (KEvEY ined.: 15 felv.), Ac: szurdokerdő (Scutellario altissimae-Aceretum pseudoplatani) (KeveY 1985: 5 felv.), Cp: gyertyános-tölgyes (Asperulo taurinaeCarpinetum) (Kevey 2016: 50 felv.), F: bükkös (Helleboro odori-Fagetum) (Kevey 1987: 50 felv.)



\section{4. ábra: Aremonio-Fagion elemek aránya a Villányi-hegység mezofil lomberdeiben}

T: törmeléklejtő-erdő (Tilio tomentosae-Fraxinetum orni) (Kevey ined.: 15 felv.), Ac: szurdokerdő (Scutellario altissimae-Aceretum pseudoplatani) (KeVEY 1985: 5 felv.), Cp: gyertyános-tölgyes (Asperulo taurinae-Carpinetum) (Kevey 2016: 50 felv.), F: bükkös (Helleboro odori-Fagetum) (KEVEY 1987: 50 felv.) 




5. ábra: Quercetea pubescentis-petraeae elemek aránya a Villányi-hegység mezofil lomberdeiben

T: törmeléklejtő-erdő (Tilio tomentosae-Fraxinetum orni) (Kevey ined.: 15 felv.), Ac: szurdokerdő (Scutellario altissimae-Aceretum pseudoplatani) (Kevey 1985: 5 felv.), Cp: gyertyános-tölgyes (Asperulo taurinae-Carpinetum) (Kevey 2016: 50 felv.), F: bükkös (Helleboro odori-Fagetum) (Kevey 1987: 50 felv.)



6. ábra: Fagetalia elemek aránya a Villányi-hegység és a Mecsek törmeléklejtö-erdeiben (Tilio tomentosae-Fraxinetum orni)

Vhg: Villányi-hegység (Kevey ined.: 15 felv.), NyM: Nyugati-Mecsek (Kevey in Kevey - Borhidi 1998: 20 felv.), KM: Keleti-Mecsek (Kevey 2007: 20 felv.) 


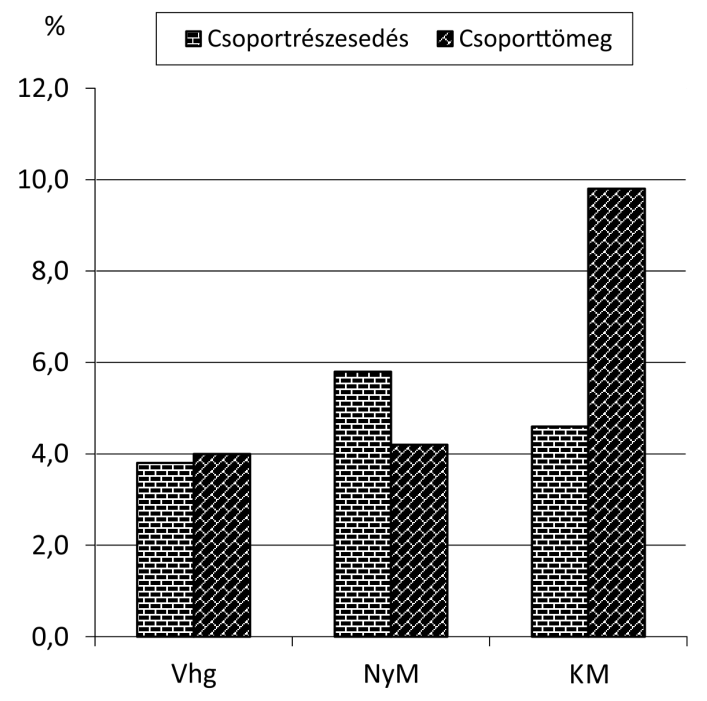

7. ábra: Tilio-Acerenion elemek aránya a Villányi-hegység és a Mecsek törmeléklejtö-erdeiben (Tilio tomentosae-Fraxinetum orni)

Vhg: Villányi-hegység (Kevey ned.: 15 felv.), NyM: Nyugati-Mecsek (KeVEY in KeVEY - BorHIDI 1998: 20 felv.), KM: Keleti-Mecsek (Kevey 2007: 20 felv.)

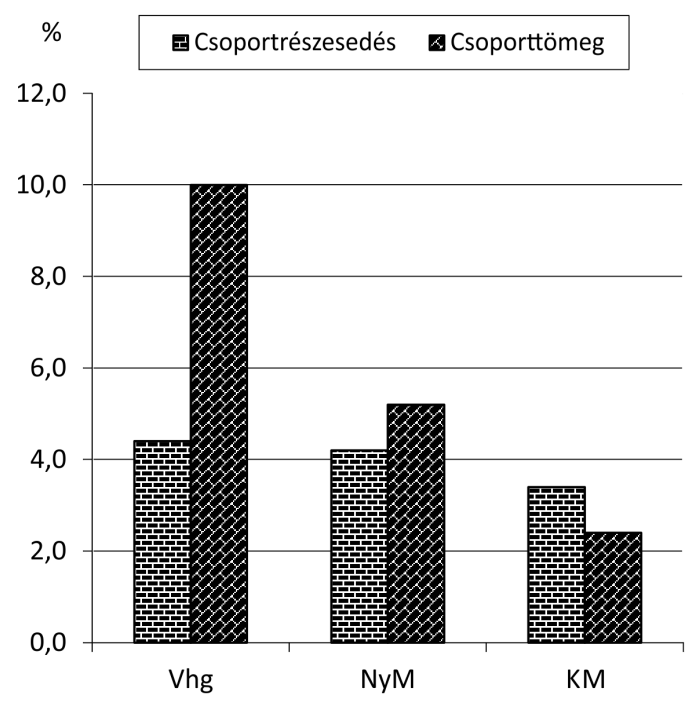

8. ábra: Aremonio-Fagion elemek aránya a Villányi-hegység és a Mecsek törmeléklejtö-erdeiben (Tilio tomentosae-Fraxinetum orni)

Vhg: Villányi-hegység (Kevey ined.: 15 felv.), NyM: Nyugati-Mecsek (Kevey in Kevey - Borhidi 1998: 20 felv.), KM: Keleti-Mecsek (Kevey 2007: 20 felv.) 




\section{9. ábra: Quercetea pubescentis-petraeae elemek aránya a Villányi-hegység és a Mecsek törmeléklejtö-erdeiben (Tilio tomentosae-Fraxinetum orni)}

Vhg: Villányi-hegység (KeveY ined.: 15 felv.), NyM: Nyugati-Mecsek (Kevey in KeveY - Borhidi 1998: 20 felv.), KM: Keleti-Mecsek (Kevey 2007: 20 felv.)

\section{Megvitatás}

BorHIDI (1961) klímazonális térképe szerint az amúgy is alacsony hegyekkel rendelkező Villányi-hegység a zárt tölgyes klímazónába tartozik. A törmeléklejtőerdőkből készült felvételek az északias lejtők sziklás részeiről készültek, mindössze 250 és 380 m közötti tengerszint feletti magasságban. Fragmentális kiterjedésű állományaik a terjedelmes gyertyános-tölgyesek (Asperulo taurinae-Carpinetum) közé vannak beékelődve, ezért az asszociáció intrazonálisnak tekinthető.

Az állandósági osztályok eloszlásánál az akcidens (K I) fajok mellett a konstans (K V) elemeknél jelentkezik egy második maximum. Ebből arra lehet következtetni, hogy a vizsgált törmeléklejtő-erdő állományok faji összetétele a Villányi-hegységben viszonylag egységesnek tekinthető. Ennek oka részben a hegység kisebb kiterjedésében keresendő.

A vizsgált törmeléklejtö-erdőkben ugyan megjelennek egyes Tilio-Acerenion jellegü karakterfajok (Acer platanoides, Asplenium trichomanes, Cystopteris fragilis, Gagea minima, Lunaria annua, Polypodium vulgare, Polystichum setiferum, Ribes-uva-crispa, Staphylea pinnata, Tilia platyphyllos, Ulmus glabra), de ezek aránya eléggé alacsony (3-4. táblázat; 3. és 7. ábra). Ennek oka elsősorban az asszociáció töredékes kiterjedésében keresendő.

A Villányi-hegység mezofil lomberdeinek (Helleboro odori-Fagetum, Asperulo taurinae-Carpinetum, Scutellario altissimae-Aceretum, Tilio tomentosae-Fraxinetum orni) elkülönítése nem könnyü (10. ábra; ERDös et al. 2017). Ennek oka nagyrészt az, hogy a szurdokerdők (Scutellario altissimae-Aceretum) és a törmeléklejtö-erdök (Tilio tomentosae-Fraxinetum orni) - a helyi domborzati viszonyok mellett - igen töredékesen van- 


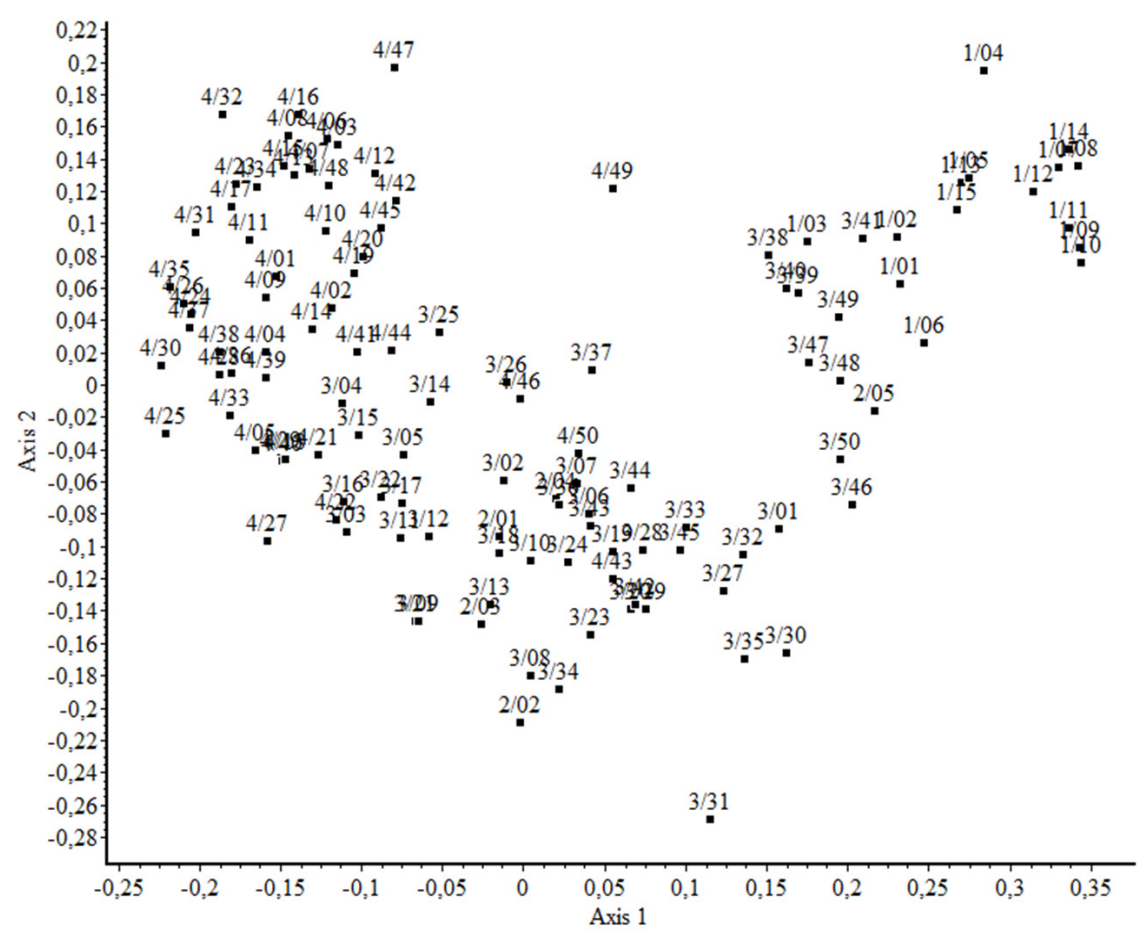

\section{0. ábra: A Villányi-hegység mezofil lomberdeinek ordinációs diagramja}

1/1-15: törmeléklejtö-erdő (Tilio tomentosae-Fraxinetum orni) (KeVEY ined.), 2/1-5: szurdokerdő (Scutellario altissimae-Aceretum pseudoplatani) (KEVEY 1985), 3/1-50: gyertyános-tölgyes (Asperulo taurinae-Carpinetum) (KeVEY 2016), 4/1-50: bükkös (Helleboro odori-Fagetum) (KeVEY 1987)

nak kifejlődve, továbbá a bükkösök (Helleboro odori-Fagetum) sem elég tipikusak. Ennek oka nagyrészt a Villányi-hegység kicsiny kiterjedése, ezzel kapcsolatban pedig domborzatának kisebb változatossága, amely a mikroklimatikus viszonyokra is kihat.

A vizsgált törmeléklejtő-erdő állományokban több szubmediterrán-illír elterjedésü növényfaj (Aremonio-Fagion és Quercion farnetto elemek) is megtalálható: Asperula taurina, Doronicum orientale, Helleborus odorus, Lathyrus venetus, Lonicera caprifolium, Lunaria annua, Polystichum setiferum, Primula vulgaris, Rosa arvensis, Ruscus aculeatus, Ruscus hypoglossum, Scutellaria altissima, Tamus communis, Tilia tomento$s a$ ). E növények a Villányi-hegység törmeléklejtö-erdeit (Tilio tomentosae-Fraxinetum orni) megkülönböztetik a Dunántúli-középhegység törmeléklejtö-erdeitől (MercurialiTilietum).

A sokváltozós elemzéseknél a Villányi-hegység és a Mecsek törmeléklejtő-erdei szépen elkülönültek (11. ábra). Ez az elkülönülés mértéke azonban kicsiny mértékü (ERDős et al. 2017), ezért a vizsgált állományok azonosíthatók a Mecsek törmeléklejtőerdeivel (Tilio tomentosae-Fraxinetum orni). Az asszociáció helye a növénytársulások rendszerében az alábbi módon vázolható: 


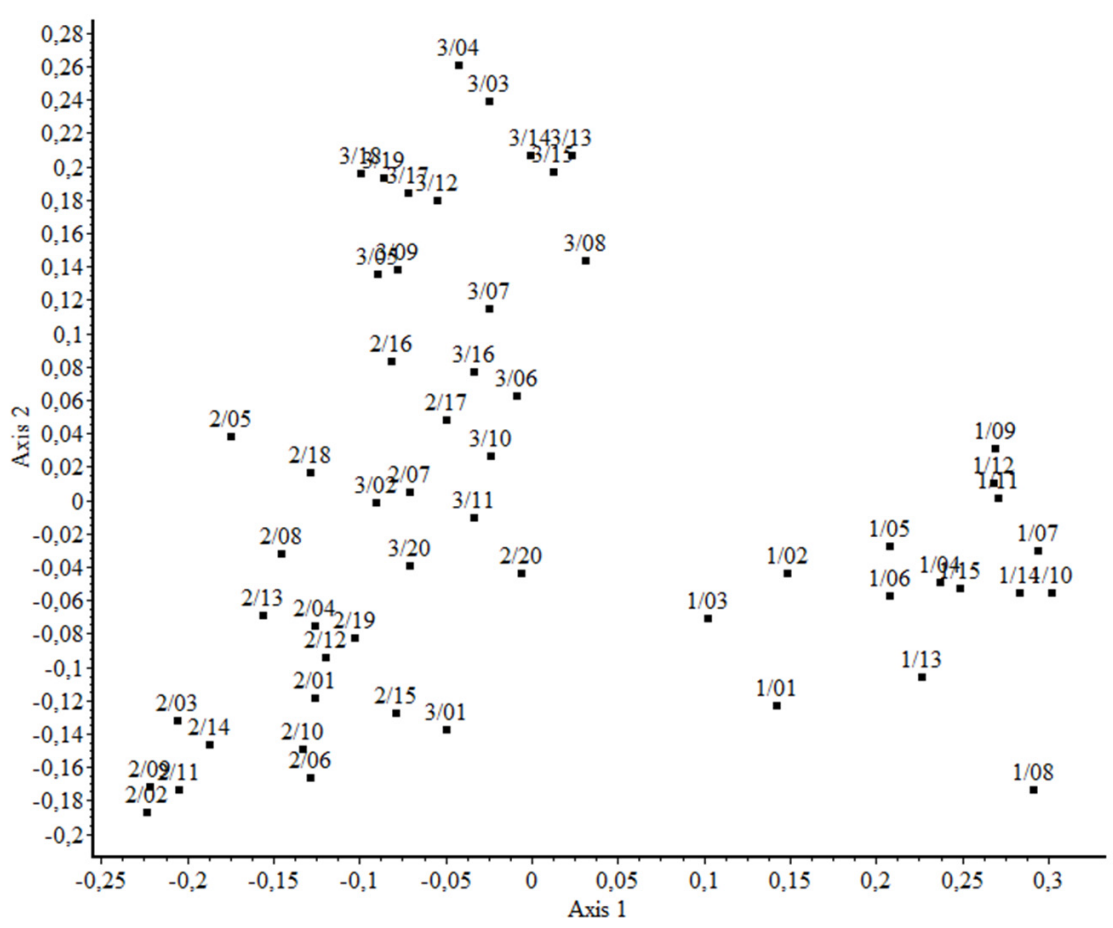

11. ábra: A Villányi-hegység és a Mecsek törmeléklejtő-erdeinek (Tilio tomentosae-Fraxinetum orni) ordinációs diagramja

1/1-15: Villányi-hegység (Kevey ined.), 2/1-20: Nyugati-Mecsek (KeveY in KevEY - BorHIDI 1998), 3/1-20: Keleti-Mecsek (KeVEY 2007)

Divízió: Querco-Fagea 1967

Osztály: Querco-Fagetea Br.-BL. \& VLIEGER in Vlieger 1937 em. BORHIDI in BORHIDI \& KEVEY 1996

Rend: Fagetalia sylvaticae PAWŁoWsKi in PAWŁowsKi et al. 1928

Csoport: Aremonio-Fagion (I. HoRVAT 1938) BORHIDI in TÖRÖK et al. 1989 Alcsoport: Polysticho setiferi-Acerenion pseudoplatani BORHIDI \& KEVEY 1996 Társulás: Tilio tomentosae-Fraxinetum orni (A. O. HoRvát 1961) Soó \& BORHIDI in Soó 1962

\section{Természetvédelmi vonatkozások}

A Villányi-hegység Natura 2000 terület. Ezen belül a Szársomlyó és a Fekete-hegy országos jelentőségü fokozottan védett természetvédelmi terület. Sajnos az évtizedek óta tervezett Villányi Tájvédelmi Körzet még mindig nem jött létre. Kétszer is megtörtént az előkészítés, de elakadt a bürokratikus akadályokon. A táj, mint legdélibb fekvésű hegységünk, hazai viszonylatban páratlan élővilággal rendelkezik, így a szubmediterránillír jellegü törmeléklejtő-erdők is vegetációnk értékes mozaikjait képezik. Az 15 felvételből 26 védett növényfaj került elő: - K V: Galanthus nivalis, Helleborus odorus, 
Ruscus aculeatus. - K IV: Asperula taurina, Tamus communis. - K III: Lilium martagon. - K II: Aconitum anthora, Dictamnus albus, Doronicum orientale, Iris variegata, Lathyrus venetus, Lonicera caprifolium, Muscari botryoides, Ornithogalum sphaerocarpum, Scilla vindobonensis. - K I: Cephalanthera damasonium, Cephalanthera longifolia, Ceterach officinarum, Digitalis ferruginea, Epipactis helleborine, Lunaria annua, Neottia nidus-avis, Orchis purpurea, Polystichum setiferum, Primula vulgaris, Ruscus hypoglossum. Közülük a Digitalis ferruginea fokozott védelem alatt áll.

Elöfordulnak egyes idegenhonos növények, amelyek a cönológiai felvételekbe is bekerültek: Ailanthus altissima, Celtis occidentalis, Juglans regia, Pinus nigra, Robinia pseudo-acacia, Stenactis annua, Vitis riparia. Közülük csak a Robinia pseudo-acacia jelent némi zavaró hatást.

A Villányi-hegység törmeléklejtő erdei (Tilio tomentosae-Fraxinetum orni) - töredékes jellegük ellenére - szubmediterrán vegetációnk értékes foltjait képezik.

\section{Összefoglalás}

Jelen tanulmány a Magyarország délnyugati részén levő Villányi-hegység törmeléklejtőerdeinek (Tilio tomentosae-Fraxinetum orni) társulási viszonyait mutatja be 15 cönológiai felvétel alapján. A vizsgált állományok a gyertyános-tölgyes klímazónán belül találhatók, északias kitettségben, sziklagörgeteges és kötörmelékes talajon. Az asszociáció viszonylag erős szubmediterrán hatás alatt áll, amelynek bizonyítéka egyes szubmediterrán-illír (Aremonio-Fagion, Quercion farnetto) jellegü fajok előfordulása: Asperula taurina, Doronicum orientale, Helleborus odorus, Lathyrus venetus, Lonicera caprifolium, Lunaria annua, Polystichum setiferum, Primula vulgaris, Rosa arvensis, Ruscus aculeatus, Ruscus hypoglossum, Scutellaria altissima, Tamus communis and Tilia tomentosa. A vizsgált törmeléklejtö-erdőkben a karakterfajok aránya hasonló, mint a közeli Mecseken. Ezzel szemben a Villányi-hegységben a Quercetea pubescentispetraeae s.l. elemek nagyobb, a Fagetalia és a Tilio-Acerenion fajok pedig kisebb szerepet játszanak, mint a Mecseken. Syntaxonomically, this community is best assigned to the „Polysticho setiferi-Acerenion pseudoplatani BorHIDI \& KeveY 1996” suballiance.

\section{Rövidítések}

A1: felső lombkoronaszint; A2: alsó lombkoronaszint; AF: Aremonio-Fagion; AFe: Asplenio-Festucion pallentis; Agi: Alnenion glutinosae-incanae; Ai: Alnion incanae; AQ: Aceri tatarici-Quercion; Ar: Artemisietea; Ara: Arrhenatheretea; Ate: Alnetea glutinosae; B1: cserjeszint; B2: újulat; Bra: Brometalia erecti; BrF: Bromo-Festucion pallentis; C: gyepszint; Cal: Calystegion sepium; Cau: Caucalidion platycarpos; Che: Chenopodietea; ChS: Chenopodio-Scleranthea; Cp: Carpinenion betuli; EP: Erico-Pinetea; Epa: Epilobietea angustifolii; EuF: Eu-Fagenion; F : Fagetalia sylvaticae; FB: Festuco-Bromea; FBt: Festuco-Brometea; Fru: Festucion rupicolae; Fvg: Festucetea vaginatae; Fvl: Festucetalia valesiacae; GA: Galio-Alliarion; ined.: ineditum (kiadatlan közlés); MoA: Molinio-Arrhenatherea; NC: Nardo-Callunetea; OCn: Orno-Cotinion; Pna: Populenion nigro-albae; PP: Pulsatillo-Pinetea; PQ: Pino-Quercetalia; Prf: Prunion fruticosae; Pru: Prunetalia spinosae; Pte: Phragmitetea; Qc: Quercetalia cerridis; Qfa: Quercion farnetto; QFt: QuercoFagetea; Qpp: Quercetea pubescentis-petraeae; Qr: Quercetalia roboris; Qrp: Quercion robori-petraeae; S: summa (összeg); Sea: Secalietea; SFe: Seslerio-Festucion pallentis; s.1.: sensu lato (tágabb értelemben); Spu: Salicetea purpureae; TA: Tilio platyphyllae-Acerenion pseudoplatani; Ulm: Ulmenion; US: UrticoSambucetea. 












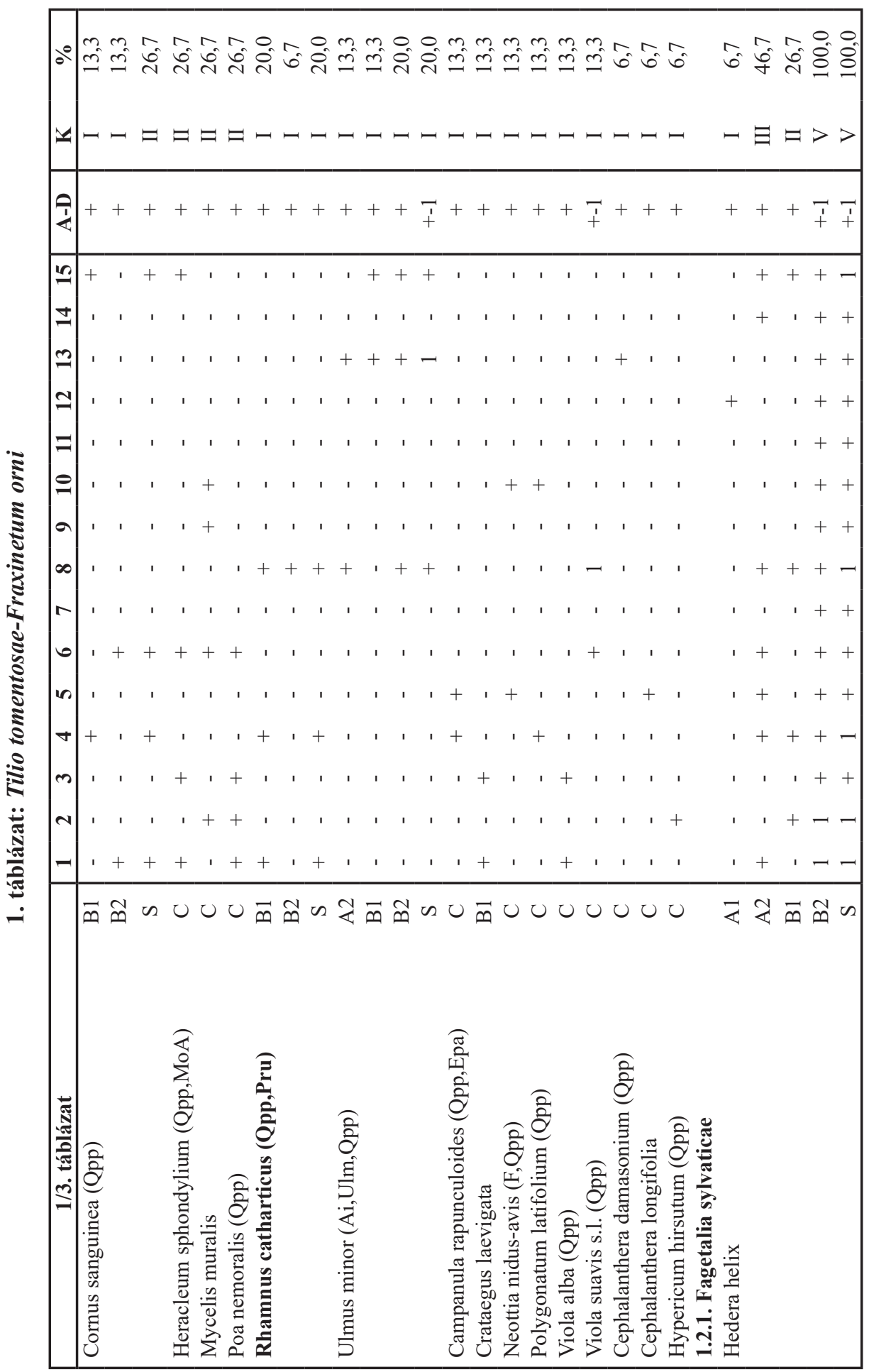




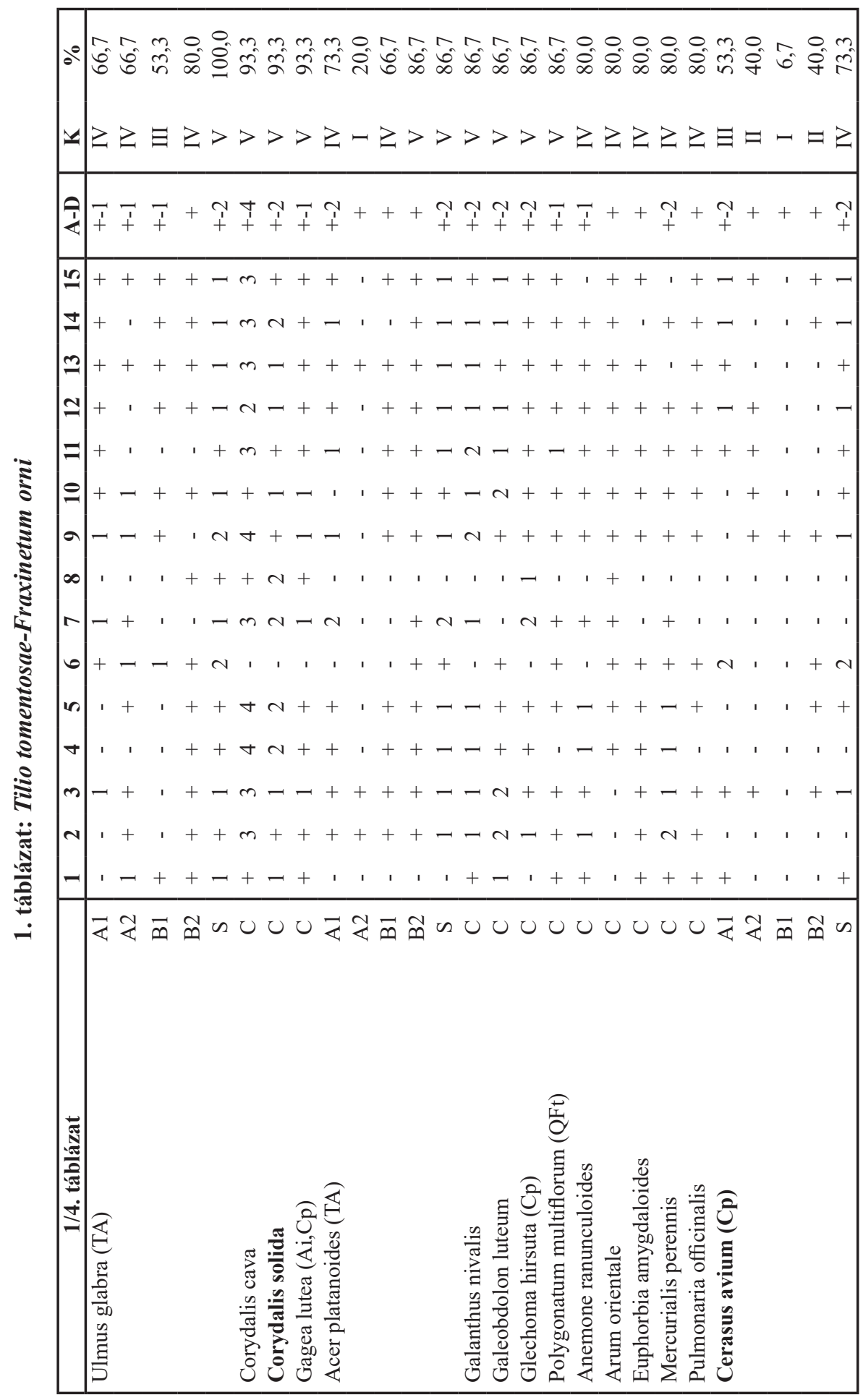









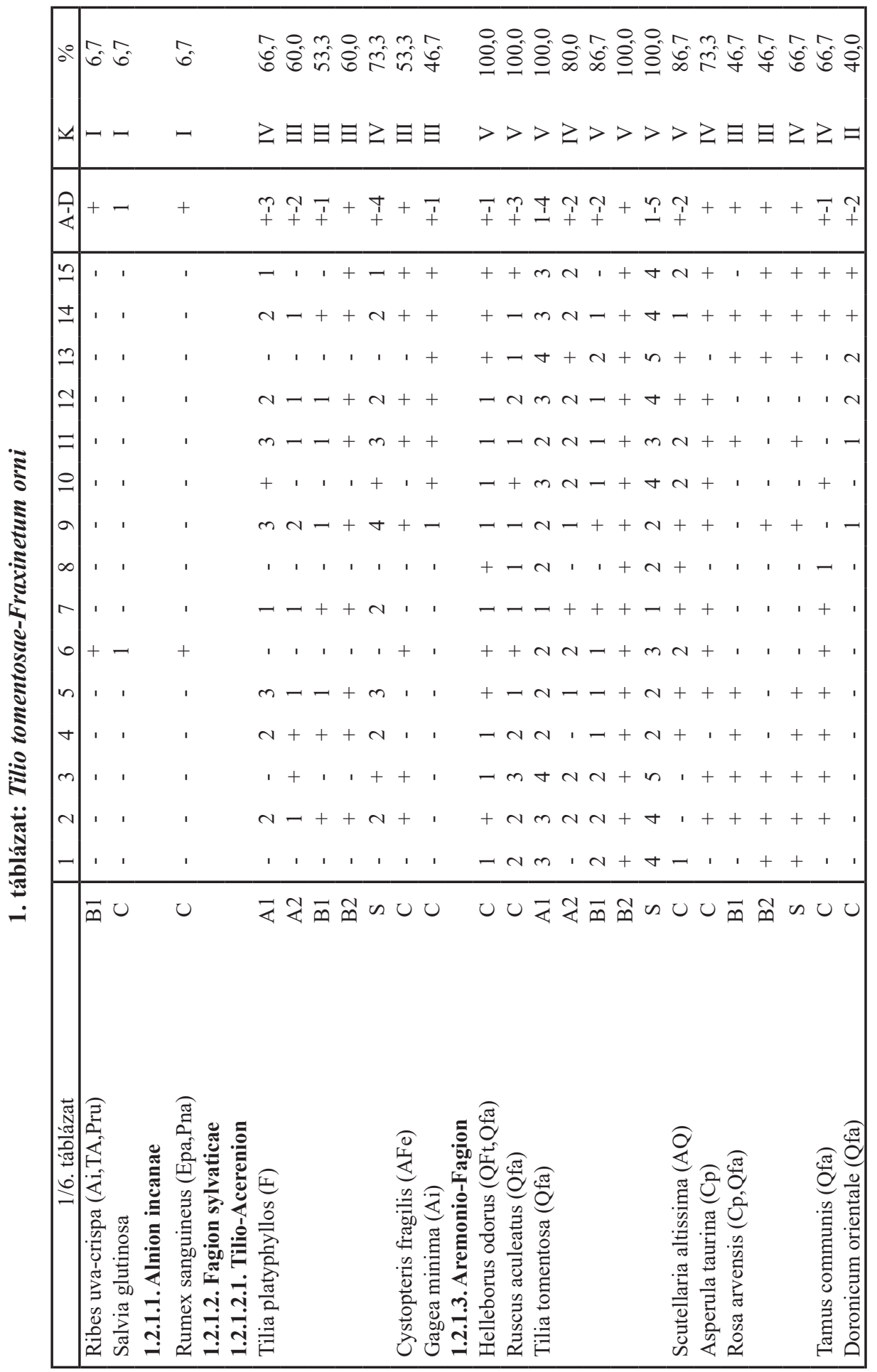




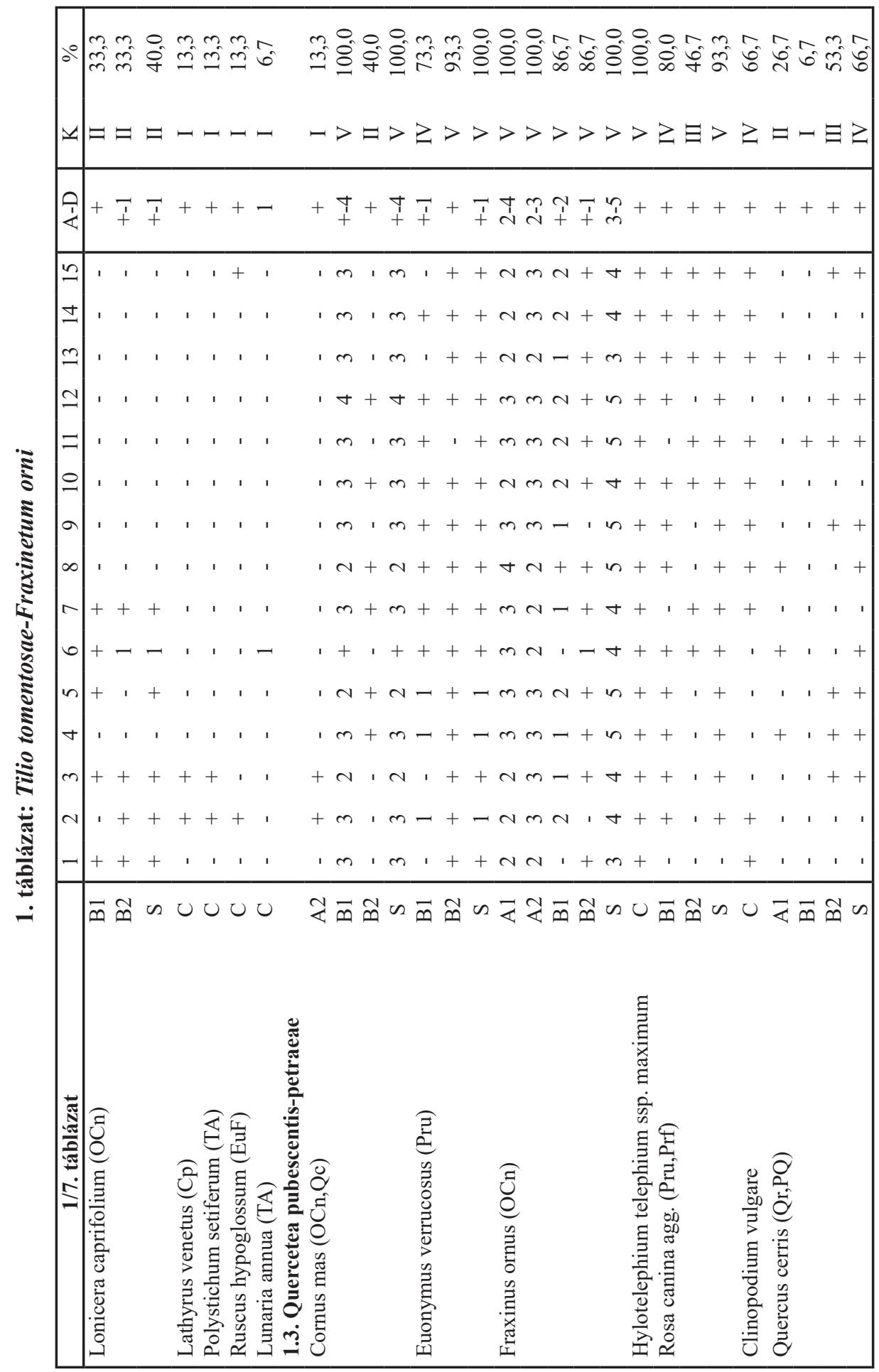




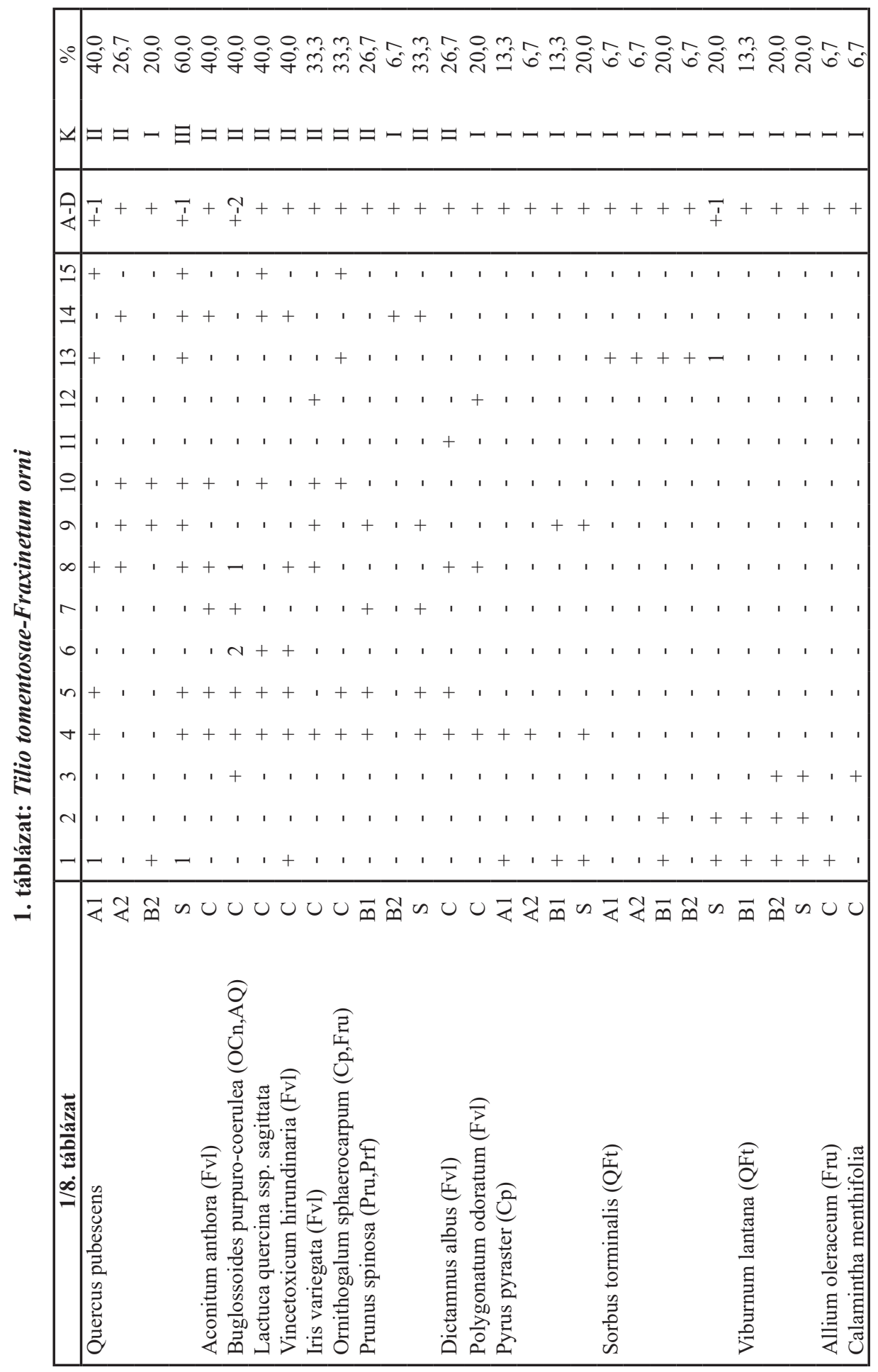









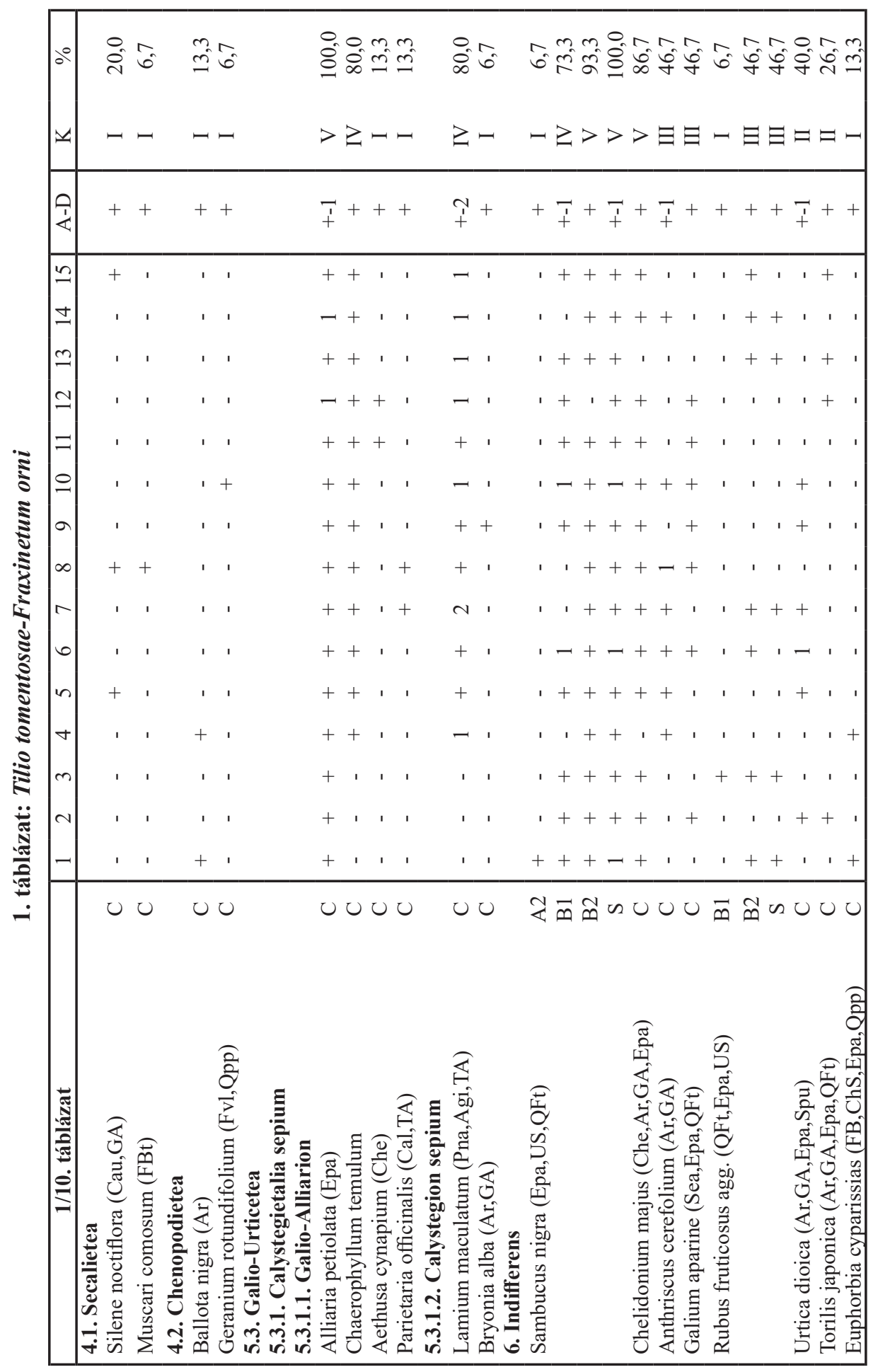




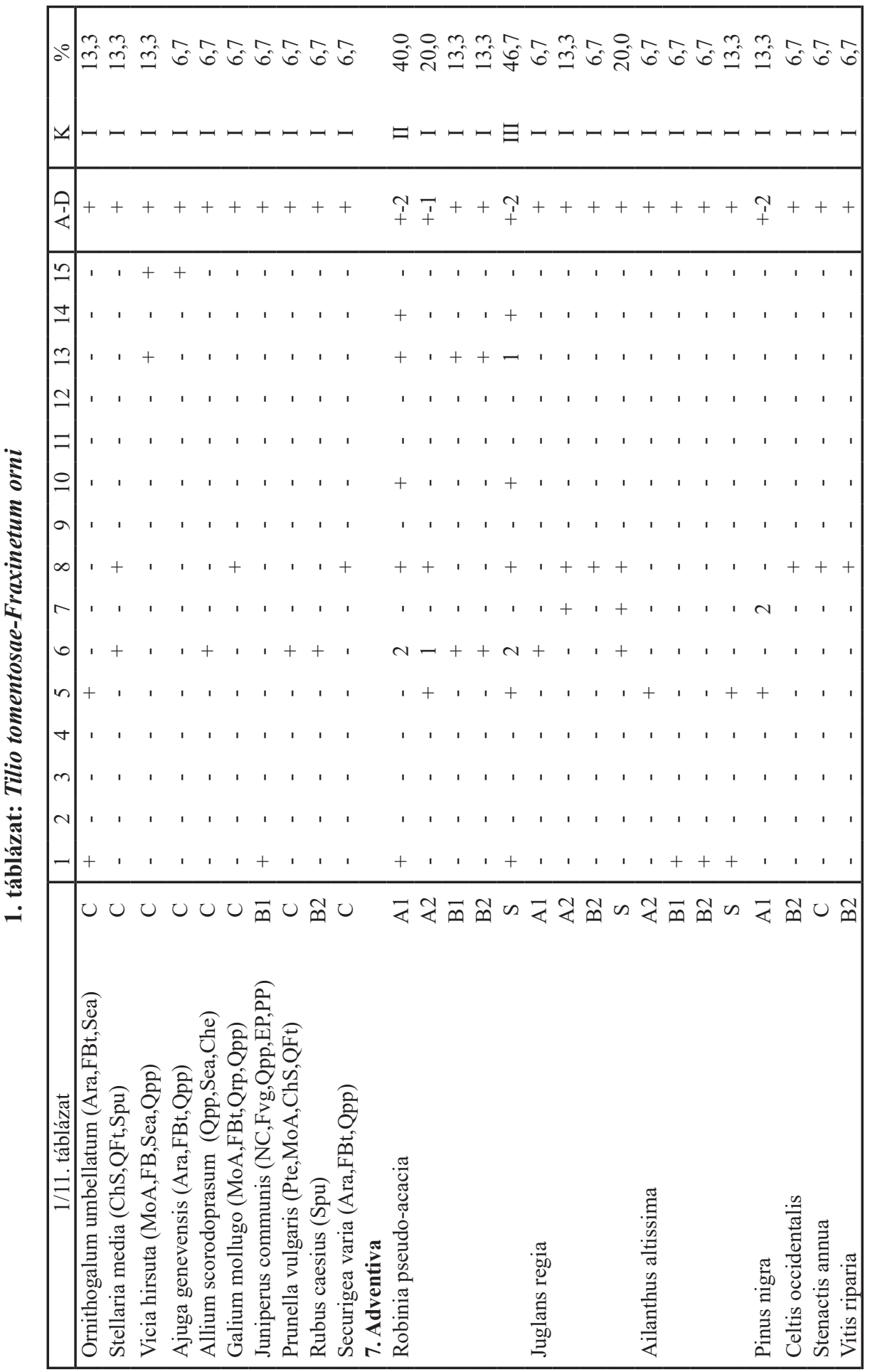







3. táblázat: Karakterfajok aránya a Villányi-hegység mezofil lomberdeiben

\begin{tabular}{|c|c|c|c|c|c|c|c|c|}
\hline \multirow{2}{*}{ 3/1. táblázat } & \multicolumn{4}{|c|}{ Csoportrészesedés } & \multicolumn{4}{|c|}{ Csoporttömeg } \\
\hline & $\mathrm{T}$ & Ac & $\mathrm{Cp}$ & $\mathrm{F}$ & $\mathrm{T}$ & Ac & $\mathrm{Cp}$ & $\mathrm{F}$ \\
\hline Querco-Fagea & 0,0 & 0,0 & 0,0 & 0,0 & 0,0 & 0,0 & 0,0 & 0,0 \\
\hline Salicetea purpureae & 0,0 & 0,0 & 0,0 & 0,0 & 0,0 & 0,0 & 0,0 & 0,0 \\
\hline Salicetalia purpureae & 0,2 & 0,4 & 0,2 & 0,0 & 0,0 & 0,1 & 0,0 & 0,0 \\
\hline Salicion albae & 0,1 & 0,1 & 0,0 & 0,0 & 0,0 & 0,0 & 0,0 & 0,0 \\
\hline Populenion nigro-albae & 0,3 & 0,2 & 0,5 & 0,1 & 0,2 & 0,0 & 0,1 & 0,0 \\
\hline Salicion albae s.l. & 0,4 & 0,3 & 0,5 & 0,1 & 0,2 & 0,0 & 0,1 & 0,0 \\
\hline Salicetalia purpureae s.l. & 0,6 & 0,7 & 0,7 & 0,1 & 0,2 & 0,1 & 0,1 & 0,0 \\
\hline Salicetea purpureae s.l. & 0,6 & 0,7 & 0,7 & 0,1 & 0,2 & 0,1 & 0,1 & 0,0 \\
\hline Alnetea glutinosae & 0,0 & 0,0 & 0,0 & 0,0 & 0,0 & 0,0 & 0,0 & 0,0 \\
\hline Alnetalia glutinosae & 0,0 & 0,1 & 0,0 & 0,0 & 0,0 & 0,0 & 0,0 & 0,0 \\
\hline Alnetea glutinosae s.l. & 0,0 & 0,1 & 0,0 & 0,0 & 0,0 & 0,0 & 0,0 & 0,0 \\
\hline Querco-Fagetea & 16,9 & 15,6 & 16,8 & 14,6 & 9,7 & 8,5 & 8,9 & 3,0 \\
\hline Fagetalia sylvaticae & 22,0 & 33,9 & 34,6 & 40,0 & 21,3 & 34,5 & 46,1 & 52,5 \\
\hline Alnion incanae & 1,2 & 2,0 & 2,4 & 0,9 & 0,5 & 0,7 & 0,9 & 0,3 \\
\hline Alnenion glutinosae-incanae & 0,3 & 0,0 & 0,2 & 0,1 & 0,2 & 0,0 & 0,0 & 0,0 \\
\hline Ulmenion & 0,1 & 0,1 & 0,1 & 0,1 & 0,0 & 0,0 & 0,0 & 0,0 \\
\hline Alnion incanae s.l. & 1,6 & 2,1 & 2,7 & 1,1 & 0,7 & 0,7 & 0,9 & 0,3 \\
\hline Fagion sylvaticae & 0,0 & 0,0 & 0,0 & 0,0 & 0,0 & 0,0 & 0,0 & 0,0 \\
\hline Eu-Fagenion & 0,4 & 1,1 & 0,7 & 1,9 & 0,1 & 7,3 & 0,6 & 19,8 \\
\hline Carpinenion betuli & 6,3 & 6,6 & 8,2 & 8,5 & 1,8 & 8,8 & 10,6 & 4,9 \\
\hline Tilio-Acerenion & 3,8 & 5,6 & 2,1 & 2,8 & 4,0 & 7,8 & 1,5 & 1,4 \\
\hline Fagion sylvaticae s.l. & 10,5 & 13,3 & 11,0 & 13,2 & 5,9 & 23,9 & 12,7 & 26,1 \\
\hline Aremonio-Fagion & 4,4 & 5,4 & 5,0 & 6,7 & 10,0 & 9,1 & 10,7 & 6,2 \\
\hline Fagetalia sylvaticae s.l. & 38,5 & 54,7 & 53,3 & 61,0 & 37,9 & 68,2 & 70,4 & 85,1 \\
\hline Quercetalia roboris & 0,4 & 0,3 & 0,4 & 0,5 & 0,0 & 0,0 & 0,4 & 0,1 \\
\hline Querco-Fagetea s.1. & 55,8 & 70,6 & 70,5 & 76,1 & 47,6 & 76,7 & 79,7 & 88,2 \\
\hline Quercetea pubescentis-petraeae & 18,1 & 8,9 & 10,9 & 11,3 & 20,5 & 6,4 & 5,9 & 3,4 \\
\hline Orno-Cotinetalia & 0,0 & 0,0 & 0,0 & 0,0 & 0,0 & 0,0 & 0,0 & 0,0 \\
\hline Orno-Cotinion & 1,6 & 1,1 & 1,5 & 2,0 & 14,4 & 3,3 & 0,8 & 1,6 \\
\hline Orno-Cotinetalia s.1. & 1,6 & 1,1 & 1,5 & 2,0 & 14,4 & 3,3 & 0,8 & 1,6 \\
\hline Quercetalia cerridis & 0,8 & 0,4 & 0,7 & 1,1 & 3,4 & 0,1 & 0,2 & 0,1 \\
\hline Quercion farnetto & 2,9 & 2,7 & 2,9 & 3,9 & 9,1 & 8,4 & 10,3 & 5,8 \\
\hline Aceri tatarici-Quercion & 0,8 & 0,4 & 0,3 & 0,1 & 0,9 & 0,1 & 0,1 & 0,0 \\
\hline Quercetalia cerridis s.l. & 4,5 & 3,5 & 3,9 & 5,1 & 13,4 & 8,6 & 10,6 & 5,9 \\
\hline Prunetalia spinosae & 1,3 & 0,1 & 0,3 & 0,4 & 0,2 & 0,0 & 0,0 & 0,1 \\
\hline Prunion fruticosae & 0,6 & 0,0 & 0,1 & 0,0 & 0,1 & 0,0 & 0,0 & 0,0 \\
\hline Prunetalia spinosae s.l. & 1,9 & 0,1 & 0,4 & 0,4 & 0,3 & 0,0 & 0,0 & 0,1 \\
\hline Quercetea pubescentis-petraeae s.l. & 26,1 & 13,6 & 16,7 & 18,8 & 48,6 & 18,3 & 17,3 & 11,0 \\
\hline Querco-Fagea s.1. & 82,5 & 85,0 & 87,9 & 95,0 & 96,4 & 95,1 & 97,1 & 99,2 \\
\hline Abieti-Piceea & 0,0 & 0,0 & 0,0 & 0,0 & 0,0 & 0,0 & 0,0 & 0,0 \\
\hline Vaccinio-Piceetea & 0,0 & 0,2 & 0,0 & 0,0 & 0,0 & 0,0 & 0,0 & 0,0 \\
\hline Pino-Quercetalia & 0,0 & 0,0 & 0,0 & 0,0 & 0,0 & 0,0 & 0,0 & 0,0 \\
\hline Pino-Quercion & 0,3 & 0,1 & 0,4 & 0,5 & 0,0 & 0,0 & 0,4 & 0,1 \\
\hline Pino-Quercetalia s.l. & 0,3 & 0,1 & 0,4 & 0,5 & 0,0 & 0,0 & 0,4 & 0,1 \\
\hline Vaccinio-Piceetea s.l. & 0,3 & 0,3 & 0,4 & 0,5 & 0,0 & 0,0 & 0,4 & 0,1 \\
\hline
\end{tabular}


3. táblázat: Karakterfajok aránya a Villányi-hegység mezofil lomberdeiben

\begin{tabular}{|c|c|c|c|c|c|c|c|c|}
\hline \multirow{2}{*}{ 3/2. táblázat } & \multicolumn{4}{|c|}{ Csoportrészesedés } & \multicolumn{4}{|c|}{ Csoporttömeg } \\
\hline & $\mathrm{T}$ & Ac & $\mathrm{Cp}$ & $\mathrm{F}$ & $\mathrm{T}$ & Ac & $\mathrm{Cp}$ & $\mathrm{F}$ \\
\hline Abieti-Piceea s.l. & 0,3 & 0,3 & 0,4 & 0,5 & 0,0 & 0,0 & 0,4 & 0,1 \\
\hline Cypero-Phragmitea & 0,0 & 0,0 & 0,0 & 0,0 & 0,0 & 0,0 & 0,0 & 0,0 \\
\hline Phragmitetea & 0,0 & 0,2 & 0,0 & 0,0 & 0,0 & 0,0 & 0,0 & 0,0 \\
\hline Cypero-Phragmitea s.1. & 0,0 & 0,2 & 0,0 & 0,0 & 0,0 & 0,0 & 0,0 & 0,0 \\
\hline Molinio-Arrhenatherea & 0,2 & 0,8 & 0,8 & 1,0 & 0,0 & 0,1 & 0,1 & 0,1 \\
\hline Molinio-Juncetea & 0,0 & 0,0 & 0,0 & 0,0 & 0,0 & 0,0 & 0,0 & 0,0 \\
\hline Molinietalia coeruleae & 0,0 & 0,0 & 0,0 & 0,1 & 0,0 & 0,0 & 0,0 & 0,0 \\
\hline Molinio-Juncetea s.1. & 0,0 & 0,0 & 0,0 & 0,1 & 0,0 & 0,0 & 0,0 & 0,0 \\
\hline Arrhenatheretea & 0,0 & 0,0 & 0,0 & 0,0 & 0,0 & 0,0 & 0,0 & 0,0 \\
\hline Arrhenatheretalia & 0,3 & 0,2 & 0,3 & 0,4 & 0,0 & 0,0 & 0,0 & 0,0 \\
\hline Arrhenatheretea s.l. & 0,3 & 0,2 & 0,3 & 0,4 & 0,0 & 0,0 & 0,0 & 0,0 \\
\hline Nardo-Callunetea & 0,0 & 0,0 & 0,0 & 0,0 & 0,0 & 0,0 & 0,0 & 0,0 \\
\hline Nardetalia & 0,0 & 0,0 & 0,0 & 0,0 & 0,0 & 0,0 & 0,0 & 0,0 \\
\hline Nardo-Agrostion tenuis & 0,0 & 0,0 & 0,0 & 0,1 & 0,0 & 0,0 & 0,0 & 0,0 \\
\hline Nardetalia s.l. & 0,0 & 0,0 & 0,0 & 0,1 & 0,0 & 0,0 & 0,0 & 0,0 \\
\hline Nardo-Callunetea s.l. & 0,0 & 0,0 & 0,0 & 0,1 & 0,0 & 0,0 & 0,0 & 0,0 \\
\hline Molinio-Arrhenatherea s.1. & 0,5 & 1,0 & 1,1 & 1,6 & 0,0 & 0,1 & 0,1 & 0,1 \\
\hline Festuco-Bromea & 0,1 & 0,0 & 0,0 & 0,0 & 0,0 & 0,0 & 0,0 & 0,0 \\
\hline Festuco-Brometea & 0,3 & 0,0 & 0,0 & 0,0 & 0,0 & 0,0 & 0,0 & 0,0 \\
\hline Festucetalia valesiacae & 1,4 & 0,0 & 0,0 & 0,0 & 0,2 & 0,0 & 0,0 & 0,0 \\
\hline Bromo-Festucion pallentis & 0,4 & 0,4 & 0,0 & 0,0 & 0,0 & 0,1 & 0,0 & 0,0 \\
\hline Seslerio-Festucion pallentis & 0,1 & 0,0 & 0,0 & 0,0 & 0,0 & 0,0 & 0,0 & 0,0 \\
\hline Asplenio-Festucion pallentis & 1,0 & 0,5 & 0,0 & 0,0 & 0,1 & 0,1 & 0,0 & 0,0 \\
\hline Festucion rupicolae & 0,2 & 0,0 & 0,1 & 0,0 & 0,0 & 0,0 & 0,0 & 0,0 \\
\hline Festucetalia valesiacae s.1. & 3,1 & 0,9 & 0,1 & 0,0 & 0,3 & 0,2 & 0,0 & 0,0 \\
\hline Festuco-Brometea s.1. & 3,4 & 0,9 & 0,1 & 0,0 & 0,3 & 0,2 & 0,0 & 0,0 \\
\hline Festuco-Bromea s.1. & 3,5 & 0,9 & 0,1 & 0,0 & 0,3 & 0,2 & 0,0 & 0,0 \\
\hline Chenopodio-Scleranthea & 0,1 & 0,3 & 0,2 & 0,0 & 0,0 & 0,1 & 0,0 & 0,0 \\
\hline Secalietea & 0,4 & 0,4 & 0,3 & 0,0 & 0,1 & 0,1 & 0,0 & 0,0 \\
\hline Secalietalia & 0,0 & 0,0 & 0,0 & 0,0 & 0,0 & 0,0 & 0,0 & 0,0 \\
\hline Caucalidion platycarpos & 0,1 & 0,0 & 0,0 & 0,0 & 0,0 & 0,0 & 0,0 & 0,0 \\
\hline Secalietalia s.l. & 0,1 & 0,0 & 0,0 & 0,0 & 0,0 & 0,0 & 0,0 & 0,0 \\
\hline Secalietea s.1. & 0,5 & 0,4 & 0,3 & 0,0 & 0,1 & 0,1 & 0,0 & 0,0 \\
\hline Chenopodietea & 0,5 & 0,4 & 0,3 & 0,0 & 0,1 & 0,1 & 0,0 & 0,0 \\
\hline Artemisietea & 0,0 & 0,0 & 0,0 & 0,0 & 0,0 & 0,0 & 0,0 & 0,0 \\
\hline Artemisietalia & 0,0 & 0,0 & 0,0 & 0,0 & 0,0 & 0,0 & 0,0 & 0,0 \\
\hline Arction lappae & 0,7 & 0,6 & 0,3 & 0,0 & 0,1 & 0,1 & 0,0 & 0,0 \\
\hline Artemisietalia s.l. & 0,7 & 0,6 & 0,3 & 0,0 & 0,1 & 0,1 & 0,0 & 0,0 \\
\hline Artemisietea s.l. & 0,7 & 0,6 & 0,3 & 0,0 & 0,1 & 0,1 & 0,0 & 0,0 \\
\hline Galio-Urticetea & 0,0 & 0,0 & 0,0 & 0,0 & 0,0 & 0,0 & 0,0 & 0,0 \\
\hline Calystegietalia sepium & 0,0 & 0,0 & 0,0 & 0,0 & 0,0 & 0,0 & 0,0 & 0,0 \\
\hline Galio-Alliarion & 3,3 & 2,3 & 2,2 & 0,1 & 0,5 & 0,4 & 0,3 & 0,0 \\
\hline Calystegion sepium & 0,4 & 0,1 & 0,3 & 0,1 & 0,2 & 0,0 & 0,0 & 0,0 \\
\hline Calystegietalia sepium s.1. & 3,7 & 2,4 & 2,5 & 0,2 & 0,7 & 0,4 & 0,3 & 0,0 \\
\hline Galio-Urticetea s.l. & 3,7 & 2,4 & 2,5 & 0,2 & 0,7 & 0,4 & 0,3 & 0,0 \\
\hline
\end{tabular}


3. táblázat: Karakterfajok aránya a Villányi-hegység mezofil lomberdeiben

\begin{tabular}{|l|c|c|c|c|c|c|c|c|}
\hline \multirow{2}{*}{ 3/3. táblázat } & \multicolumn{3}{|c|}{ Csoportrészesedés } & \multicolumn{3}{c|}{ Csoporttömeg } \\
\cline { 2 - 8 } & $\mathrm{T}$ & $\mathrm{Ac}$ & $\mathrm{Cp}$ & $\mathrm{F}$ & $\mathrm{T}$ & $\mathrm{Ac}$ & $\mathrm{Cp}$ & $\mathrm{F}$ \\
\hline Epilobietea angustifolii & 0,0 & 0,0 & 0,0 & 0,0 & 0,0 & 0,0 & 0,0 & 0,0 \\
Epilobietalia & 3,9 & 4,2 & 4,1 & 1,8 & 1,0 & 1,4 & 1,0 & 0,3 \\
Epilobion angustifolii & 0,0 & 0,3 & 0,2 & 0,0 & 0,0 & 0,0 & 0,0 & 0,0 \\
Atropion bella-donnae & 0,0 & 0,3 & 0,1 & 0,0 & 0,0 & 0,0 & 0,0 & 0,0 \\
Epilobietalia s.1. & 3,9 & 4,8 & 4,4 & 1,8 & 1,0 & 1,4 & 1,0 & 0,3 \\
Epilobietea angustifolii s.1. & 3,9 & 4,8 & 4,4 & 1,8 & 1,0 & 1,4 & 1,0 & 0,3 \\
Urtico-Sambucetea & 0,0 & 0,0 & 0,0 & 0,0 & 0,0 & 0,0 & 0,0 & 0,0 \\
Sambucetalia & 0,0 & 0,0 & 0,0 & 0,0 & 0,0 & 0,0 & 0,0 & 0,0 \\
Sambuco-Salicion capreae & 0,5 & 0,9 & 0,7 & 0,6 & 0,1 & 0,9 & 0,4 & 0,1 \\
Sambucetalia s.1. & 0,5 & 0,9 & 0,7 & 0,6 & 0,1 & 0,9 & 0,4 & 0,1 \\
Urtico-Sambucetea s.1. & 0,5 & 0,9 & 0,7 & 0,6 & 0,1 & 0,9 & 0,4 & 0,1 \\
Chenopodio-Scleranthea s.1. & 9,9 & 9,8 & 8,7 & 2,6 & 2,1 & 3,1 & 1,7 & 0,4 \\
Indifferens & 1,5 & 1,6 & 0,9 & 0,1 & 0,2 & 1,0 & 0,2 & 0,0 \\
Adventiva & 1,6 & 1,2 & 0,7 & 0,0 & 0,9 & 0,4 & 0,4 & 0,0 \\
\hline
\end{tabular}

T: Tilio tomentosae-Fraxinetum orni, Villányi-hegység (KeVEY ined.: 15 felv.)

Ac: Scutellario altissimae-Aceretum pseudo-platani, Villányi-hegység (KeVEY 1985: 5 felv.)

Cp: Asperulo taurinae-Carpinetum, Villányi-hegység (Kevey 2016: 50 felv.)

F: Helleboro odori-Fagetum, Villányi-hegység (Kevey 1987: 50 felv.) 


\section{4. táblázat: Karakterfajok aránya a Villányi-hegység és a Mecsek törmeléklejtö-erdeiben (Tilio tomentosae-Fraxinetum orni)}

\begin{tabular}{|c|c|c|c|c|c|c|}
\hline \multirow{2}{*}{ 4/1. táblázat } & \multicolumn{3}{|c|}{ Csoportrészesedés } & \multicolumn{3}{|c|}{ Csoporttömeg } \\
\hline & T-Vhg & T-NyM & $\mathrm{T}-\mathrm{KM}$ & T-Vhg & T-NyM & $\mathrm{T}-\mathrm{KM}$ \\
\hline Querco-Fagea & 0,0 & 0,0 & 0,0 & 0,0 & 0,0 & 0,0 \\
\hline Salicetea purpureae & 0,0 & 0,0 & 0,0 & 0,0 & 0,0 & 0,0 \\
\hline Salicetalia purpureae & 0,2 & 0,0 & 0,1 & 0,0 & 0,0 & 0,0 \\
\hline Salicion albae & 0,1 & 0,0 & 0,0 & 0,0 & 0,0 & 0,0 \\
\hline Populenion nigro-albae & 0,3 & 0,2 & 0,4 & 0,2 & 0,1 & 0,6 \\
\hline Salicion albae s.l. & 0,4 & 0,2 & 0,4 & 0,2 & 0,1 & 0,6 \\
\hline Salicetalia purpureae s.l. & 0,6 & 0,2 & 0,5 & 0,2 & 0,1 & 0,6 \\
\hline Salicetea purpureae s.l. & 0,6 & 0,2 & 0,5 & 0,2 & 0,1 & 0,6 \\
\hline Alnetea glutinosae & 0,0 & 0,0 & 0,0 & 0,0 & 0,0 & 0,0 \\
\hline Alnetalia glutinosae & 0,0 & 0,0 & 0,0 & 0,0 & 0,0 & 0,0 \\
\hline Alnetea glutinosae s.l. & 0,0 & 0,0 & 0,0 & 0,0 & 0,0 & 0,0 \\
\hline Querco-Fagetea & 16,9 & 15,4 & 16,5 & 9,7 & 7,0 & 11,0 \\
\hline Fagetalia sylvaticae & 22,0 & 32,4 & 31,1 & 21,3 & 29,6 & 33,7 \\
\hline Alnion incanae & 1,2 & 0,5 & 1,2 & 0,5 & 0,1 & 0,3 \\
\hline Alnenion glutinosae-incanae & 0,3 & 0,7 & 0,5 & 0,2 & 0,2 & 0,6 \\
\hline Ulmenion & 0,1 & 0,0 & 0,1 & 0,0 & 0,0 & 0,0 \\
\hline Alnion incanae s.l. & 1,6 & 1,2 & 1,8 & 0,7 & 0,3 & 0,9 \\
\hline Fagion sylvaticae & 0,0 & 0,0 & 0,0 & 0,0 & 0,0 & 0,0 \\
\hline Eu-Fagenion & 0,4 & 1,6 & 1,5 & 0,1 & 8,2 & 6,6 \\
\hline Carpinenion betuli & 6,3 & 7,4 & 7,0 & 1,8 & 5,4 & 5,4 \\
\hline Tilio-Acerenion & 3,8 & 5,8 & 4,6 & 4,0 & 4,2 & 9,8 \\
\hline Fagion sylvaticae s.l. & 10,5 & 14,8 & 13,1 & 5,9 & 17,8 & 21,8 \\
\hline Aremonio-Fagion & 4,4 & 4,2 & 3,4 & 10,0 & 5,2 & 2,4 \\
\hline Fagetalia sylvaticae s.l. & 38,5 & 52,6 & 49,4 & 37,9 & 52,9 & 58,8 \\
\hline Quercetalia roboris & 0,4 & 0,6 & 0,5 & 0,0 & 0,5 & 0,2 \\
\hline Quercion robori-petraeae & 0,0 & 0,1 & 0,1 & 0,0 & 0,0 & 0,0 \\
\hline Quercetalia roboris s.1. & 0,4 & 0,7 & 0,6 & 0,0 & 0,5 & 0,2 \\
\hline Querco-Fagetea s.l. & 55,8 & 68,7 & 66,5 & 47,6 & 60,4 & 70,0 \\
\hline Quercetea pubescentis-petraeae & 18,1 & 14,2 & 13,8 & 20,5 & 16,1 & 14,1 \\
\hline Orno-Cotinetalia & 0,0 & 0,0 & 0,0 & 0,0 & 0,0 & 0,0 \\
\hline Orno-Cotinion & 1,6 & 1,1 & 1,1 & 14,4 & 11,8 & 6,5 \\
\hline Orno-Cotinetalia s.l. & 1,6 & 1,1 & 1,1 & 14,4 & 11,8 & 6,5 \\
\hline Quercetalia cerridis & 0,8 & 0,9 & 0,6 & 3,4 & 3,5 & 1,7 \\
\hline Quercion farnetto & 2,9 & 2,3 & 2,3 & 9,1 & 4,8 & 2,2 \\
\hline Quercion petraeae & 0,0 & 1,0 & 0,7 & 0,0 & 0,2 & 0,1 \\
\hline Aceri tatarici-Quercion & 0,8 & 0,3 & 0,3 & 0,9 & 0,1 & 0,1 \\
\hline Quercetalia cerridis s.l. & 4,5 & 4,5 & 3,9 & 13,4 & 8,6 & 4,1 \\
\hline Prunetalia spinosae & 1,3 & 0,7 & 0,4 & 0,2 & 0,1 & 0,1 \\
\hline Prunion fruticosae & 0,6 & 0,1 & 0,1 & 0,1 & 0,0 & 0,0 \\
\hline Prunetalia spinosae s.l. & 1,9 & 0,8 & 0,5 & 0,3 & 0,1 & 0,1 \\
\hline Quercetea pubescentis-petraeae s.l. & 26,1 & 20,6 & 19,3 & 48,6 & 36,6 & 24,8 \\
\hline Querco-Fagea s.1. & 82,5 & 89,5 & 86,3 & 96,4 & 97,1 & 95,4 \\
\hline
\end{tabular}




\section{4. táblázat: Karakterfajok aránya a Villányi-hegység és a Mecsek törmeléklejtő-erdeiben (Tilio tomentosae-Fraxinetum orni)}

\begin{tabular}{|c|c|c|c|c|c|c|}
\hline \multirow{2}{*}{ 4/2. táblázat } & \multicolumn{3}{|c|}{ Csoportrészesedés } & \multicolumn{3}{|c|}{ Csoporttömeg } \\
\hline & T-Vhg & T-NyM & T-KM & T-Vhg & T-NyM & $\mathrm{T}-\mathrm{KM}$ \\
\hline Abieti-Piceea & 0,0 & 0,0 & 0,0 & 0,0 & 0,0 & 0,0 \\
\hline Pulsatillo-Pinetea & 0,0 & 0,0 & 0,0 & 0,0 & 0,0 & 0,0 \\
\hline Pulsatillo-Pinetalia & 0,0 & 0,0 & 0,0 & 0,0 & 0,0 & 0,0 \\
\hline Festuco vaginatae-Pinion & 0,0 & 0,1 & 0,0 & 0,0 & 0,0 & 0,0 \\
\hline Pulsatillo-Pinetalia s.l. & 0,0 & 0,1 & 0,0 & 0,0 & 0,0 & 0,0 \\
\hline Pulsatillo-Pinetea s.l. & 0,0 & 0,1 & 0,0 & 0,0 & 0,0 & 0,0 \\
\hline Vaccinio-Piceetea & 0,0 & 0,1 & 0,1 & 0,0 & 0,0 & 0,0 \\
\hline Pino-Quercetalia & 0,0 & 0,0 & 0,0 & 0,0 & 0,0 & 0,0 \\
\hline Pino-Quercion & 0,3 & 0,7 & 0,5 & 0,0 & 0,6 & 0,2 \\
\hline Pino-Quercetalia s.1. & 0,3 & 0,7 & 0,5 & 0,0 & 0,6 & 0,2 \\
\hline Vaccinio-Piceetea s.l. & 0,3 & 0,8 & 0,6 & 0,0 & 0,6 & 0,2 \\
\hline Abieti-Piceea s.l. & 0,3 & 0,9 & 0,6 & 0,0 & 0,6 & 0,2 \\
\hline Cypero-Phragmitea & 0,0 & 0,0 & 0,0 & 0,0 & 0,0 & 0,0 \\
\hline Phragmitetea & 0,0 & 0,0 & 0,0 & 0,0 & 0,0 & 0,0 \\
\hline Cypero-Phragmitea s.l. & 0,0 & 0,0 & 0,0 & 0,0 & 0,0 & 0,0 \\
\hline Molinio-Arrhenatherea & 0,2 & 0,5 & 0,4 & 0,0 & 0,1 & 0,1 \\
\hline Arrhenatheretea & 0,0 & 0,0 & 0,0 & 0,0 & 0,0 & 0,0 \\
\hline Arrhenatheretalia & 0,3 & 0,2 & 0,2 & 0,0 & 0,0 & 0,0 \\
\hline Arrhenatheretea s.l. & 0,3 & 0,2 & 0,2 & 0,0 & 0,0 & 0,0 \\
\hline Nardo-Callunetea & 0,0 & 0,0 & 0,0 & 0,0 & 0,0 & 0,0 \\
\hline Nardetalia & 0,0 & 0,0 & 0,0 & 0,0 & 0,0 & 0,0 \\
\hline Nardo-Agrostion tenuis & 0,0 & 0,1 & 0,0 & 0,0 & 0,0 & 0,0 \\
\hline Nardetalia s.1. & 0,0 & 0,1 & 0,0 & 0,0 & 0,0 & 0,0 \\
\hline Nardo-Callunetea s.l. & 0,0 & 0,1 & 0,0 & 0,0 & 0,0 & 0,0 \\
\hline Calluno-Ulicetea & 0,0 & 0,0 & 0,0 & 0,0 & 0,0 & 0,0 \\
\hline Vaccinio-Genistetalia & 0,0 & 0,0 & 0,0 & 0,0 & 0,0 & 0,0 \\
\hline Calluno-Genistion & 0,0 & 0,0 & 0,1 & 0,0 & 0,0 & 0,0 \\
\hline Vaccinio-Genistetalia s.l. & 0,0 & 0,0 & 0,1 & 0,0 & 0,0 & 0,0 \\
\hline Calluno-Ulicetea s.1. & 0,0 & 0,0 & 0,1 & 0,0 & 0,0 & 0,0 \\
\hline Molinio-Arrhenatherea s.l. & 0,5 & 0,8 & 0,7 & 0,0 & 0,1 & 0,1 \\
\hline Festuco-Bromea & 0,1 & 0,1 & 0,1 & 0,0 & 0,0 & 0,0 \\
\hline Festuco-Brometea & 0,3 & 0,2 & 0,1 & 0,0 & 0,0 & 0,0 \\
\hline Festucetalia valesiacae & 1,4 & 0,4 & 0,4 & 0,2 & 0,1 & 0,1 \\
\hline Bromo-Festucion pallentis & 0,4 & 0,4 & 0,1 & 0,0 & 0,1 & 0,0 \\
\hline Seslerio-Festucion pallentis & 0,1 & 0,0 & 0,0 & 0,0 & 0,0 & 0,0 \\
\hline Asplenio-Festucion pallentis & 1,0 & 0,8 & 0,4 & 0,1 & 0,2 & 0,1 \\
\hline Festucion rupicolae & 0,2 & 0,0 & 0,0 & 0,0 & 0,0 & 0,0 \\
\hline Festucetalia valesiacae s.l. & 3,1 & 1,6 & 0,9 & 0,3 & 0,4 & 0,2 \\
\hline Festuco-Brometea s.1. & 3,4 & 1,8 & 1,0 & 0,3 & 0,4 & 0,2 \\
\hline Festuco-Bromea s.l. & 3,5 & 1,9 & 1,1 & 0,3 & 0,4 & 0,2 \\
\hline
\end{tabular}




\section{4. táblázat: Karakterfajok aránya a Villányi-hegység és a Mecsek törmeléklejtö-erdeiben (Tilio tomentosae-Fraxinetum orni)}

\begin{tabular}{|c|c|c|c|c|c|c|}
\hline \multirow{2}{*}{ 4/3. táblázat } & \multicolumn{3}{|c|}{ Csoportrészesedés } & \multicolumn{3}{|c|}{ Csoporttömeg } \\
\hline & T-Vhg & T-NyM & T-KM & T-Vhg & T-NyM & T-KM \\
\hline Chenopodio-Scleranthea & 0,1 & 0,0 & 0,2 & 0,0 & 0,0 & 0,0 \\
\hline Secalietea & 0,4 & 0,1 & 0,2 & 0,1 & 0,0 & 0,0 \\
\hline Secalietalia & 0,0 & 0,0 & 0,0 & 0,0 & 0,0 & 0,0 \\
\hline Caucalidion platycarpos & 0,1 & 0,0 & 0,0 & 0,0 & 0,0 & 0,0 \\
\hline Secalietalia s.l. & 0,1 & 0,0 & 0,0 & 0,0 & 0,0 & 0,0 \\
\hline Secalietea s.l. & 0,5 & 0,1 & 0,2 & 0,1 & 0,0 & 0,0 \\
\hline Chenopodietea & 0,5 & 0,3 & 0,3 & 0,1 & 0,1 & 0,1 \\
\hline Artemisietea & 0,0 & 0,0 & 0,0 & 0,0 & 0,0 & 0,0 \\
\hline Artemisietalia & 0,0 & 0,0 & 0,0 & 0,0 & 0,0 & 0,0 \\
\hline Arction lappae & 0,7 & 0,3 & 0,5 & 0,1 & 0,1 & 0,1 \\
\hline Artemisietalia s.l. & 0,7 & 0,3 & 0,5 & 0,1 & 0,1 & 0,1 \\
\hline Artemisietea s.l. & 0,7 & 0,3 & 0,5 & 0,1 & 0,1 & 0,1 \\
\hline Galio-Urticetea & 0,0 & 0,0 & 0,0 & 0,0 & 0,0 & 0,0 \\
\hline Calystegietalia sepium & 0,0 & 0,0 & 0,0 & 0,0 & 0,0 & 0,0 \\
\hline Galio-Alliarion & 3,3 & 1,7 & 3,8 & 0,5 & 0,4 & 1,4 \\
\hline Calystegion sepium & 0,4 & 0,2 & 0,4 & 0,2 & 0,1 & 0,6 \\
\hline Calystegietalia sepium s.1. & 3,7 & 1,9 & 4,2 & 0,7 & 0,5 & 2,0 \\
\hline Galio-Urticetea s.l. & 3,7 & 1,9 & 4,2 & 0,7 & 0,5 & 2,0 \\
\hline Epilobietea angustifolii & 0,0 & 0,0 & 0,0 & 0,0 & 0,0 & 0,0 \\
\hline Epilobietalia & 3,9 & 3,1 & 4,0 & 1,0 & 0,7 & 1,2 \\
\hline Epilobion angustifolii & 0,0 & 0,0 & 0,0 & 0,0 & 0,0 & 0,0 \\
\hline Atropion bella-donnae & 0,0 & 0,2 & 0,3 & 0,0 & 0,0 & 0,0 \\
\hline Epilobietalia s.l. & 3,9 & 3,3 & 4,3 & 1,0 & 0,7 & 1,2 \\
\hline Epilobietea angustifolii s.l. & 3,9 & 3,3 & 4,3 & 1,0 & 0,7 & 1,2 \\
\hline Urtico-Sambucetea & 0,0 & 0,0 & 0,0 & 0,0 & 0,0 & 0,0 \\
\hline Sambucetalia & 0,0 & 0,0 & 0,0 & 0,0 & 0,0 & 0,0 \\
\hline Sambuco-Salicion capreae & 0,5 & 0,3 & 0,4 & 0,1 & 0,1 & 0,3 \\
\hline Sambucetalia s.1. & 0,5 & 0,3 & 0,4 & 0,1 & 0,1 & 0,3 \\
\hline Urtico-Sambucetea s.1. & 0,5 & 0,3 & 0,4 & 0,1 & 0,1 & 0,3 \\
\hline Chenopodio-Scleranthea s.l. & 9,9 & 6,2 & 10,1 & 2,1 & 1,5 & 3,7 \\
\hline Indifferens & 1,5 & 0,7 & 1,1 & 0,2 & 0,1 & 0,4 \\
\hline Adventiva & 1,6 & 0,0 & 0,1 & 0,9 & 0,0 & 0,0 \\
\hline
\end{tabular}

Vhg: Villányi-hegység (Kevey ined.: 15 felv.)

NyM: Nyugati-Mecsek (KeveY in KeveY - BorhIDI 1998: 20 felv.)

KM: Keleti-Mecsek (KeVEy 2006: 20 felv.) 


\section{Irodalom}

Becking, R. W. 1957: The Zürich-Montpellier School of phytosociology. - Botanical Review 23: 411-488.

Borhid, A. 1961: Klimadiagramme und klimazonale Karte Ungarns. - Annales Universitatis Scientiarum Budapestinensis, Sectio Biologica 4: 21-250.

Borhidi A. 1993: A magyar flóra szociális magatartás típusai, természetességi és relatív ökológiai értékszámai. - Janus Pannonius Tudományegyetem, Pécs, 95 pp.

BorHIDI, A. 1995: Social behaviour types, the naturalness and relative ecological indicator values of the higher plants in the hungarian flora. - Acta Botanica Academiae Scientiarum Hungaricae 39: 97-181.

Borhid, A. \& KeVEY, B. 1996: An annotated checklist of the hungarian plant communities II. - In: BorHIDI A. (ed.): Critical revision of the hungarian plant communities. - Janus Pannonius University, Pécs, pp. 95-138.

Borhidi, A., Kevey, B. \& Lendvai, G. 2012: Plant communities of Hungary. - Akadémiai Kiadó, Budapest, 544 pp.

Braun-Blanquet, J. 1964: Pflanzensoziologie (ed. 3.). - Springer Verlag, Wien-New York, 865 pp.

Erdös L., Bátori Z., Tölgyesi, Cs. \& Kevey, B. 2017: The Illyrian mesic forrests od the Villány Mts: phytosociology and conservation importance. - Biologia 72(5): 510-519.

Horvát A. O. 1961: A Keleti Mecsek északi részének erdei növénytársulásai. - Dunántúli Tudományos Gyüjtemény 26, Series Geographica 15: 93-106.

Honvát, A. O. 1972: Die Vegetation des Mecsekgebirges und seiner Umgebung. - Akadémiai Kiadó, Budapest, $376 \mathrm{pp}$.

HoRVAT, I. 1938: Biljnosociološka istraživanja šuma u Hrvatskoj. - Glasnik za šumske pokuse 6:127-256.

Horváth F., Dobolyi Z. K., MorschHauser T., LőKös L., Karas L. \& Szerdahelyi T. 1995: Flóra adatbázis 1.2. - Vácrátót, $267 \mathrm{pp}$.

JAKUCS, P. 1967: Gedanken zur höheren Systematik der europäischen Laubwälder. - Contribuții Botanici Cluj 1967: 159-166.

Kevey B. 1985: Fragmentális szurdokerdők a Villányi-hegységben. - A Janus Pannonius Múzeum Évkönyve 29 (1984): 23-28.-

Kevey B. 1987: A Villányi-hegység bükkösei. The beech-woods of the Villány Mountains, South Hungary. - A Janus Pannonius Múzeum Évkönyve 30-31 (1985-1986): 7-9. + 1 táblázat.

Kevey, B. 2007: A new forest association in Hungary: Thermophilous dry oakwood on rubble (Paeonio banaticae-Quercetum cerris KeVEY ass. nova). - Hacquetia, Ljubljana 6 (1): 5-59.

Kevey B. 2016: A Villányi-hegység gyertyános-tölgyesei [Asperulo taurinae-Carpinetum (A. O. HoRvát 1946) Soó et Borhidi in Soó 1962]. - Acta Naturalia Pannonica 10: 21-46.

Kevey B. 2008: Magyarország erdőtársulásai (Forest associations of Hungary). - Tilia 14: 1-488. + CD-adatbázis (230 táblázat +244 ábra).

Kevey, B. \& Borhidi, A. 1998: Top-forest (Aconito anthorae-Fraxinetum orni) a special ecotonal case in the phytosociological system (Mecsek mts, South Hungary). - Acta Botanica Academiae Scientiarum Hungaricae 41: 27-121.

Kevey B., \& Hirmann A. 2002: „NS” számítógépes cönológiai programcsomag. - In: Aktuális flóra- és vegetációkutatások a Kárpát-medencében V. Pécs, 2002. március 8-10. (Összefoglalók), pp.: 74.

KIRÁly G. (szerk.) 2009: Új magyar füvészkönyv. Magyarország hajtásos növényei. Határozókulcsok. Aggteleki Nemzeti Park Igazgatóság, Jósvafő, 616 pp.

Lovász Gy., \& WeIn Gy. 1974: Délkelet-Dunántúl geológiája és felszínfejlődése. - Baranya Megyei Levéltár, Pécs, 215 pp. +1 chart.

Mucina, L., Grabherr, G., \& WallnöFer, S. 1993: Die Pflanzengesellschaften Österreichs III. Wälder und Gebüsche. - Gustav Fischer Verlag, Jena-Stuttgart-New York, 353 pp.

Oberdorfer, E. 1992: Süddeutsche Pflanzengesellschaften IV. A. Textband. - Gustav Fischer Verlag, JenaStuttgart-New York, 282 pp.

Pawlowski, B., Sokolowski, M. \& Wallisch, K. 1928: Die Pflanzenassoziationen des Tatra-Gebirges VII. Die Pflanzenassoziationen und die Flora des Morskie Oko-Tales. - Bulletin International de l'Academie Polonaise des Sciences et Lettres; Classe des Sciences Mathématiques et Naturelles; Série B: Sciences Naturelles 1927: 205-272.

PoDANI, J. 2001: SYN-TAX 2000 Computer Programs for Data Analysis in Ecologi and Systematics. - Scientia, Budapest, 53 pp.

Soó, R. 1962: Systematische Übersicht der pannonischen Pflanzengesellschaften V. Die Gebirgswälder I. Acta Botanica Academiae Scientiarum Hungaricae 8: 335-366. 
Soó R. 1964, 1966, 1968, 1970, 1973, 1980: A magyar flóra és vegetáció rendszertani-növényföldrajzi kézikönyve I-VI. - Akadémiai kiadó, Budapest.

TÖRÖK K., PODANI, J. \& BorHIDI, A. 1989: Numerical revision of Fagion illyricum alliance. - Vegetatio 81: 169-180.

VliegE,R, J. 1937: Aperçu sur les unités phytosociologiques supérieures des Pays-Bas. - Nederlandsch Kruidkundig Archief 47: 335.

Wallnöfer, S., Mucina, L. \& Grass, V. 1993: Querco-Fagetea. - In: Die Pflanzengesellschaften Österreichs III. (eds. Mucina, L., Grabherr, G. \& Wallnöfer, S.). - Gustav Fischer Verlag, Jena-Stuttgart-New York, pp. 85-236. 